\title{
Syngas Fermentation: A Microbial Conversion Process of Gaseous Substrates to Various Products
}

\author{
John R. Phillips, Raymond L. Huhnke and Hasan K. Atiyeh * \\ Biosystems and Agricultural Engineering Department, Oklahoma State University, 214 Ag Hall, Stillwater, \\ OK 74078, USA; rphi@ostatemail.okstate.edu (J.R.P.); raymond.huhnke@okstate.edu (R.L.H.) \\ * Correspondence: hasan.atiyeh@okstate.edu; Tel.: +1-405-744-8397; Fax: +1-405-744-6059
}

Received: 27 April 2017; Accepted: 12 June 2017; Published: 16 June 2017

\begin{abstract}
Biomass and other carbonaceous materials can be gasified to produce syngas with high concentrations of $\mathrm{CO}$ and $\mathrm{H}_{2}$. Feedstock materials include wood, dedicated energy crops, grain wastes, manufacturing or municipal wastes, natural gas, petroleum and chemical wastes, lignin, coal and tires. Syngas fermentation converts $\mathrm{CO}$ and $\mathrm{H}_{2}$ to alcohols and organic acids and uses concepts applicable in fermentation of gas phase substrates. The growth of chemoautotrophic microbes produces a wide range of chemicals from the enzyme platform of native organisms. In this review paper, the Wood-Ljungdahl biochemical pathway used by chemoautotrophs is described including balanced reactions, reaction sites physically located within the cell and cell mechanisms for energy conservation that govern production. Important concepts discussed include gas solubility, mass transfer, thermodynamics of enzyme-catalyzed reactions, electrochemistry and cellular electron carriers and fermentation kinetics. Potential applications of these concepts include acid and alcohol production, hydrogen generation and conversion of methane to liquids or hydrogen.
\end{abstract}

Keywords: syngas fermentation; acetyl-CoA pathway; acetogen; biofuel; gasification

\section{Introduction to Syngas Fermentation}

Syngas fermentation is a hybrid thermochemical/biochemical platform that takes advantage of the simplicity of the gasification process and the specificity of the fermentation process to deliver ethanol and potentially other chemicals. Biomass is converted to ethanol through the thermochemical platform, i.e., gasification and the biological platform, i.e., fermentation in syngas fermentation [1]. Energy-rich biomass and waste materials are converted by gasification to syngas, which consists of $\mathrm{CO}, \mathrm{H}_{2}$ and $\mathrm{CO}_{2}$. These gases are then converted to ethanol and other chemicals by acetogenic autotrophic microbes [2]. These microorganisms, "possess a very valuable (trait)" have "the ability to grow in strict autotrophy" and "to produce added-value compounds" [3]. After twenty five years of syngas fermentation research for the production of ethanol, this application is now being deployed at a near commercial scale. However, "these studies have yet to define a methodology for generating high ethanol production levels with stable culture." [4]. In this paper, we present a review of feedstocks, syngas production, metabolic pathway, bioreactor design, mass transfer, thermodynamics, electrochemistry and microbial kinetics of the syngas fermentation process and propose a conceptual model to describe the syngas fermentation.

A process flow diagram for the conversion of switchgrass, a dedicated perennial energy crop, to ethanol is shown in Figure 1. Switchgrass is first converted to syngas in gasification with $\mathrm{O}_{2}$ and/or steam. $\mathrm{CO}$ and $\mathrm{H}_{2}$ from the cooled syngas is utilized by the bacterial culture in fermentation for cell growth and product synthesis. Beer from the fermentation is then distilled to recover ethanol, and the bottom stream from distillation is returned to the fermentation. Recovered ethanol, taken from overhead of the distillation column, is processed using a molecular sieve to achieve the final product specification. 


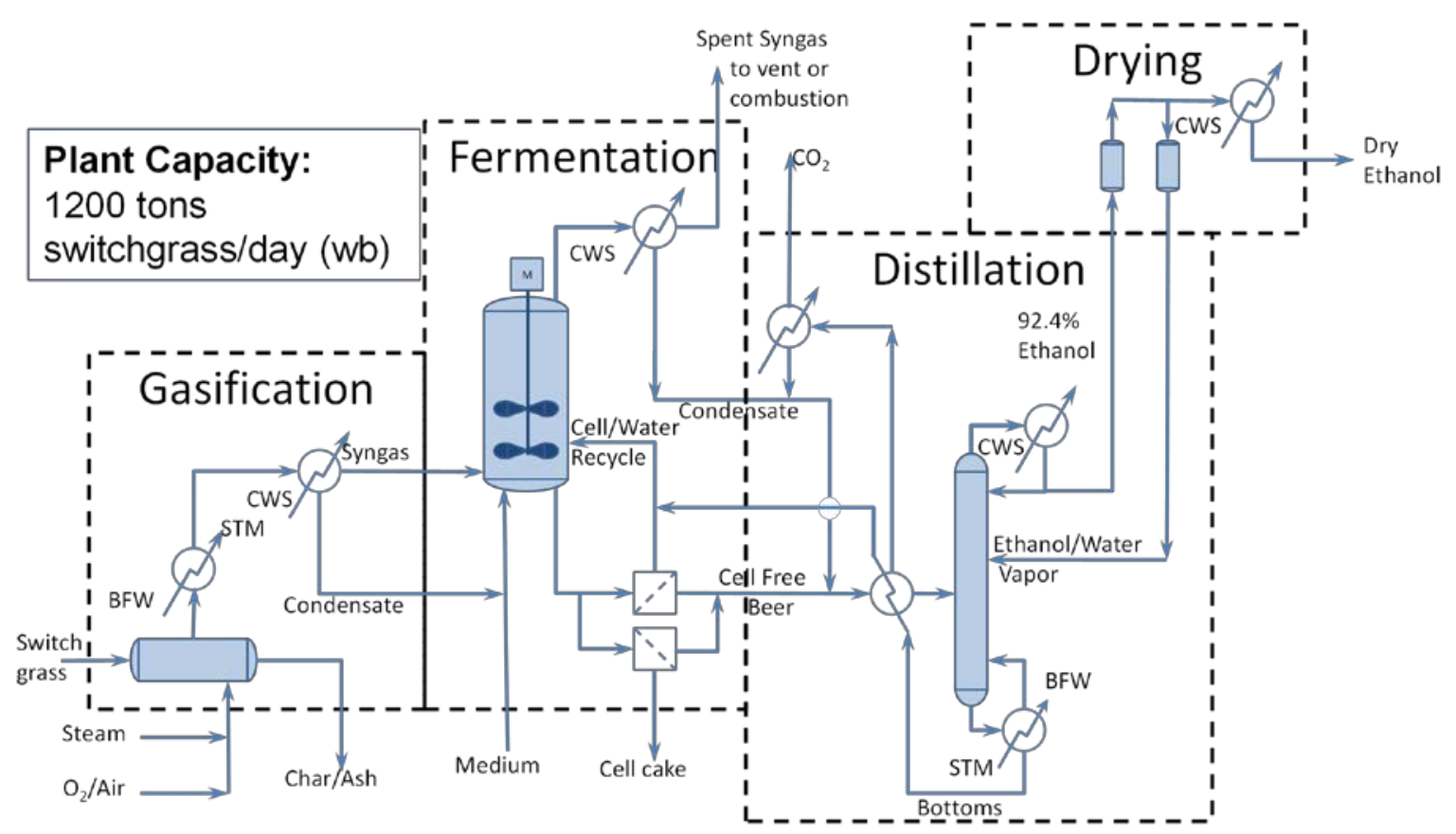

Figure 1. Process flow diagram for the gasification of switchgrass followed by syngas fermentation to produce fuel ethanol; BFW: boiler feedwater system; STM: steam; Syngas: synthesis gas; CWS: circulating water system; wb: wet basis.

A key consideration in any fuel process is preserving the energy content of the feedstock in the final product. Energy is expended in each production step; after solid biomass is heated to a high temperature for the gasification step, energy is recovered from the syngas as steam, and heat is lost to the environment. Energy diverted to cell growth, heat lost from the fermenter, unconverted syngas and unrecovered acetic acid represent energy diverted from the ethanol product. The economy of the fermentation process is enhanced through improvements in efficiency that conserve energy and increase product yield. Energy efficiency represented by retaining the higher heating value from the products, through gasification [5] and as increased product yield from fermentation [6], and the use of energy efficient separation technologies, such as membrane separation, are very important to achieve a profitable commercial process for fuels or chemicals.

\subsection{Energy Demand}

World energy demand is expected to grow from 553 exajoules $\left(1 \mathrm{EJ}=10^{18} \mathrm{~J}=0.948\right.$ quadrillion BTU $=0.948$ Quad) in 2012 to 865 EJ in 2040 per the U.S. Energy Information Administration's International Energy Outlook for 2013 [7,8]. The world demand for transportation fuels is also projected to rise from $182 \mathrm{EJ}$ in 2010 to $249 \mathrm{EJ}$ in 2040 (from 182 to 229 trillion liters of petroleum). Consumption of liquid biofuels will increase from 2.78 EJ in 2010 (77.2 trillion liters of gasoline equivalent) to $6.21 \mathrm{EJ}$ projected in 2040 (172.4 trillion liters gasoline equivalent).

\subsection{Potential Resources}

Balan [9] compiled an extensive list of projects for the development of lignocellulosic biofuels supported by the governments of the U.S. and the EU that have achieved a range of success. Syngas fermentation projects have advanced to commercial scale $[10,11]$. The accounting of biofuels by the EIA includes biomass-to-liquids (BTL) and biodiesel; while ethanol remains the most prominent liquid fuel from biomass. BTL also includes pyrolysis oil and Fischer-Tropsch liquids that share similar thermochemical processes with gasification. Additional sources of syngas include gasification of coal and steam reforming of natural gas. 


\subsubsection{Biomass}

The major portion of projected U.S. biofuels consumption of $1.84 \mathrm{EJ}$ in 2012, rising to $2.34 \mathrm{EJ}$ in 2040 [12], is from ethanol with consumption of $1.71 \mathrm{EJ}$ in 2012 almost exclusively supplied from corn, rising to $1.99 \mathrm{EJ}$ in 2040 with less than 1\% projected to derive from cellulosic feedstock. These projections reflect lowered expectations due to slow progress in the technical and economic competence of cellulosic fuel production, coupled with the increased reserves for U.S. oil and gas production. However, global capacity to produce biomass for energy production is projected as 11 to 28 billion tonnes by 2050 [13], which represents 200 to 500 EJ annually.

\subsubsection{Wastes}

In addition to forest and agriculture wastes, municipal solids wastes (MSW) can be an energy resource. Combustible material discarded in the U.S. municipal waste stream is estimated at about 117 million tonnes [14] representing about 2 EJ potential for energy production with only small increase expected through 2030. Use of MSW combined with chemical and petroleum wastes in syngas production may be important as an environmentally-sound management practice. Paper mill wood wastes and black liquor can supply syngas for energy production [15]. These materials are a gathered resource with a negative value, incurring cost for disposal, and represent an opportunity for energy production with environmental benefit.

\subsection{Syngas Production}

Gasification of biomass to produce syngas provides the simple precursors $\mathrm{CO}$ and $\mathrm{H}_{2}$ for fermentation. Atsonios et al. [15] published a process flow diagram for similar production of syngas (followed by catalytic mixed alcohol synthesis). When gasification is coupled with fermentation of the syngas, the robustness and adaptability of the acetogenic bacteria reduce the requirements for gas cleaning and adjustment by the water gas shift reaction required for catalytic conversion of syngas.

Liew et al. [11] discussed a fixed-bed, a circulating fluidized bed (CFB) and entrained flow gasifiers, with preference for CFB for biomass and entrained flow for liquids and solids that are easily pulverized. For syngas fermentation, low pressure and high temperature in the gasification chamber promote $\mathrm{CO}$ and $\mathrm{H}_{2}$ formation and reduce higher molecular weight hydrocarbons or "tar" in the syngas produced, and an atmospheric indirect heated CFB is preferred [5].

Biomass and waste materials contain nitrogen, sulfur, chlorine and other constituent elements, in addition to complex hydrocarbon structures, such as aromatics that decompose slowly in gasification. These compounds remain in the syngas product as $\mathrm{N}_{2}$ and other minor components, such as ammonia $\left(\mathrm{NH}_{3}\right)$, hydrogen sulfide $\left(\mathrm{H}_{2} \mathrm{~S}\right)$ and tars [16,17]. Residual hydrocarbon tars can foul equipment surfaces and orifices and can be inhibitory in fermentation along with chemical species produced in combustion like hydrogen cyanide (HCN). Woolcock and Brown [18] presented an extensive review of syngas contaminants, gas specifications for particular applications and technologies used for gas cleanup. Some chemical species that poison chemical catalysts such as $\mathrm{NH}_{3}$, carbonyl sulfide (COS) and $\mathrm{H}_{2} \mathrm{~S}$ can be used as nutrient components for the growth of the acetogenic bacteria when present at low levels. Fermentation uses syngas with a composition dependent on the type of gasifier used and its operating conditions. Fermentation can simplify the process flow diagram for syngas cleaning and emissions treatment, lowering capital requirements compared to catalytic processes, such as Fischer-Tropsch.

\subsection{Microbial Conversion of $\mathrm{CO}$ and $\mathrm{H}_{2}$}

Acetogenic bacteria convert $\mathrm{CO}, \mathrm{H}_{2}$ and $\mathrm{CO}_{2}$ derived from biomass or waste materials into acetic acid [2]. It is theorized that the acetogenic pathway is as old as life on the Earth [19] and has been optimized by evolution to ensure the survival of species that produce acetyl coenzyme A (acetyl-CoA) from small molecules in natural environments. Acetyl-CoA is an intermediate metabolite that is converted to synthesize cell mass and complex chemicals and yields organic acids and alcohols, most 
easily acetic acid and ethanol. Production of acetic acid supplies energy for synthesis of cell mass, including lipids, proteins and other complex cell components from the simple inorganic gas substrates $\left(\mathrm{CO}, \mathrm{H}_{2}\right.$ and $\left.\mathrm{CO}_{2}\right)$. The ability of some acetogens to reduce organic acids to alcohols, particularly acetic acid to ethanol, is the basis for biofuel production. Knowledge of the acetogenic mechanisms supports successful process design for energy conservation in biofuels' production.

The use of dedicated biomass energy crops, waste biomass and municipal and industrial wastes as feedstock for energy and chemical synthesis promotes reuse and recycling of materials consumed in our society. This can establish a true cycle of renewable, carbon-neutral, energy and chemical production.

\section{Chemoautotrophic Microbes}

The bacteria used in syngas fermentation belong to a group of prokaryotic single cell organisms termed "acetogens", which are defined by the use of the acetyl-CoA pathway for reductive synthesis of acetyl-CoA from $\mathrm{CO}_{2}$, energy conservation for growth and assimilation of carbon from $\mathrm{CO}$ and $\mathrm{CO}_{2}$ into biomass [2]. The cellular mechanisms of acetogenesis are present and used by bacteria, archaea and eukaryotes alike. Acetogens inhabit a wide range of ecosystems and have diverse capacities for substrate utilization and product formation, dependent on the growth environment.

Acetogenesis was recognized in 1932 when the production of acetic acid from $\mathrm{H}_{2}$ and $\mathrm{CO}_{2}$ by sewage sludge was reported [20]. Subsequently, Klass Wieringa [21] isolated Clostridium aceticum, demonstrating synthesis of acetic acid from $\mathrm{H}_{2} / \mathrm{CO}_{2}$ by this pure culture. The type culture for acetogenesis, Clostridium thermoaceticum, reclassified as Moorella thermoacetica [22], was isolated by Francis Fontaine [23]. Harland Wood and Lars Ljungdahl studied the acetyl-CoA pathway, providing the definition of the incorporation of $\mathrm{CO}$ and of the tetrahydrofolate (THF)-dependent reduction of $\mathrm{CO}_{2}$ to a methyl group, in the formation of acetyl-CoA. The acetyl-CoA pathway is also referred to as the Wood-Ljungdahl pathway of autotrophic growth. A detailed description of the history of the discovery of acetogenesis is given in a review [2], and the enzymology is reviewed by Ragsdale [24].

\subsection{Species and Habitat}

Drake et al. [2] cited 100 species of acetogens, from 22 genera in his review. These acetogens were of various morphologies (rods, cocci and spirochetes) with a wide range of temperature optima from 5 to $62{ }^{\circ} \mathrm{C}$. Acetogens were isolated from a wide variety of habitats including soil, sewage sludge, feces, rumen fluid, sediments and industrial wastes. The $\mathrm{pH}$ conditions ranged from alkaline to acidic, and most habitats were not strictly anoxic.

The first acetogen reported to produce ethanol from syngas was Clostridium ljungdahlii $[25,26]$. Shortly thereafter, Butyribacterium methylotrophicum was reported to produce butanol and ethanol from CO [27]. Other prominent species of acetogenic alcohol producers are C. autoethanogenum [28], C. carboxidivorans, which has also been shown to synthesize butanol and hexanol [29,30], and C. ragsdalei [31]. New species continue to be discovered, including moderately alkaliphilic acetogens that produce ethanol; for example, Alkalibaculum bacchi represents yet another new genus and species [32,33].

Mixed culture syngas fermentations for the production of ethanol and acetic acid and conversion of organic acids to their respective alcohols were also reported [34,35]. Enrichment of acetogens in chicken manure in India [4] and cow manure in China [36] shows the potential of natural inocula. However, Clostridium difficile and C. sordellii, acetogenic human pathogens, were detected in the enriched fermentation [36], which suggests that extreme caution should be exercised in the selection and use of syngas fermenting microorganisms.

The diversity and habitat of acetogens show the potential for additional species to be discovered. A range of fermentative capabilities may be expected from this diverse population, promising new products from syngas fermentation. Successful production using acetogens will likely use the conditions to which the strain has adapted through evolution. The natural environment has a limited source of $\mathrm{CO}$, and acetogens have developed mechanisms that scavenge $\mathrm{H}_{2}$ to fix $\mathrm{CO}_{2}$ very 
effectively via the autotrophic pathways. Nutrients essential to the growth of functional cell mass are the object of competition between a consortium of bacteria and other organisms. Efficient mechanisms for nutrient uptake are required for the bacteria to thrive especially in the environment with very low nutrient concentrations. Isolation of acetogens typically uses a medium enriched with yeast extract with pH stabilized using a Good's buffer, like 2-(N-morpholino)ethanesulfonic Acid (MES) [37]. Several studies have substituted other complex medium components for yeast extract; for example, corn steep liquor [38,39] or cotton seed extract [40]. A defined medium without complex nutrients was used with C. ljungdahlii to achieve $48 \mathrm{~g} / \mathrm{L}$ of ethanol [41].

Culture methods were modified to control mass transfer for successful growth of $C$. carboxidivorans in defined medium and produce butanol and hexanol [30].

\subsection{Structure}

Acetogens are found as rods, cocci and spirochetes and can be either Gram-positive or Gram-negative [2]. The typical ethanol producing acetogen is a rod-shaped Gram-positive motile bacterium that can form spores. C. carboxidivorans, also known as strain P7, is described as "Gram-positive, motile rods $(0.5 \times 3 \mu \mathrm{m})$ occurring singly and in pairs. Cells rarely sporulate, but spores are subterminal to terminal with slight cell swelling. Obligate anaerobe with an optimum growth temperature of $38{ }^{\circ} \mathrm{C}$ and an optimum $\mathrm{pH}$ of 6.2. Grows autotrophically with $\mathrm{H}_{2} / \mathrm{CO}_{2}$ or $\mathrm{CO}$ and chemoorganotrophically" [29].

The cell membrane is a phospholipid bilayer embedded with proteins, which divides the cytoplasm from the external environment and mediates cell function [42]. Fifteen enzymes closely associated with the acetyl-CoA pathway [24] are listed in Table 1.

Table 1. Enzymes of the acetyl-CoA (Wood-Ljungdahl) pathway.

\begin{tabular}{|c|c|c|}
\hline Enzyme & Reaction & Reference \\
\hline Carbon Monoxide dehydrogenase & $\mathrm{CO}+\mathrm{H}_{2} \mathrm{O} \rightarrow \mathrm{CO}_{2}+2 \mathrm{H}^{+}+2 \mathrm{e}^{-}$ & [43] \\
\hline Hydrogenase & $\mathrm{H}_{2} \rightarrow 2 \mathrm{H}^{+}+2 \mathrm{e}^{-}$ & [44] \\
\hline Ferredoxin oxidoreductase & $\mathrm{Fd}_{\mathrm{Rd}} \rightarrow \mathrm{Fd}_{\mathrm{Ox}}+2 \mathrm{e}^{-}$ & [45] \\
\hline Formate dehydrogenase & $\mathrm{CO}_{2}+\mathrm{NADPH} \rightarrow \mathrm{HCOO}^{-}+\mathrm{NADP}^{+}$ & [46] \\
\hline Formate kinase & $\mathrm{HCOO}^{-}+\mathrm{ATP}^{4-}+\mathrm{H}^{+} \rightarrow \mathrm{HCOOPO}_{3}^{-}+\mathrm{ADP}^{3-}$ & [47] \\
\hline Formyl THF synthetase ${ }^{1}$ & $\mathrm{HCOOPO}_{3}{ }^{-}+\mathrm{THF} \rightarrow \mathrm{HCOTHF}+\mathrm{HPO}_{4}{ }^{2-}+\mathrm{H}^{+}$ & [48] \\
\hline Methenyl THF cyclohydrolase & $\mathrm{HCOTHF}+\mathrm{H}^{+} \rightarrow \mathrm{HC}^{+} \mathrm{THF}+\mathrm{H}_{2} \mathrm{O}$ & [44] \\
\hline Methylene THF dehydrogenase & $\mathrm{HC}^{+} \mathrm{THF}+\mathrm{NADPH} \rightarrow \mathrm{H}_{2} \mathrm{CTHF}+\mathrm{NADP}^{+}$ & [49] \\
\hline Methylene THF reductase & $\mathrm{H}_{2} \mathrm{CTHF}+2 \mathrm{H}^{+}+2 \mathrm{e}^{-} \rightarrow \mathrm{H}_{3} \mathrm{CTHF}$ & [50] \\
\hline Methyl transferase & $\mathrm{H}_{3} \mathrm{CTHF}+\mathrm{H}^{+}+\left[\mathrm{Co}^{+}\right] \mathrm{E}^{2+} \rightarrow \mathrm{THF}+\mathrm{H}_{3} \mathrm{C}\left[\mathrm{Co}^{3+}\right] \mathrm{E}^{+}$ & [44] \\
\hline Corrinoid-Iron-Sulfur protein & {$\left[\mathrm{Co}^{+}\right] \mathrm{E}^{2+}$} & [51] \\
\hline Acetyl-CoA synthase & $\mathrm{H}_{3} \mathrm{C}\left[\mathrm{Co}^{3+}\right] \mathrm{E}^{+}+\mathrm{CO}+\mathrm{CoASH} \rightarrow \mathrm{CH}_{3} \mathrm{COSCoA}+\left[\mathrm{Co}^{+}\right] \mathrm{E}^{2+}+\mathrm{H}^{+}$ & [24] \\
\hline Phosphotransacetylase & $\mathrm{CH}_{3} \mathrm{COSCoA}+\mathrm{HPO}_{4}^{2-}+\mathrm{H}^{+} \rightarrow \mathrm{CH}_{3} \mathrm{COOHPO}_{3}^{-}+\mathrm{CoASH}$ & [52] \\
\hline Acetate kinase & $\mathrm{CH}_{3} \mathrm{COOHPO}_{3}^{-}+\mathrm{ADP}^{3-} \rightarrow \mathrm{CH}_{3} \mathrm{COO}^{-}+\mathrm{ATP}^{4-}+\mathrm{H}^{+}$ & [52] \\
\hline Aldehyde dehydrogenase & $\mathrm{CH}_{3} \mathrm{COO}^{-}+\mathrm{NADPH}+2 \mathrm{H}^{+} \rightarrow \mathrm{CH}_{3} \mathrm{CHO}+\mathrm{NADP}^{+}+\mathrm{H}_{2} \mathrm{O}$ & [53] \\
\hline Alcohol dehydrogenase & $\mathrm{CH}_{3} \mathrm{CHO}+\mathrm{NADPH}+\mathrm{H}^{+} \rightarrow \mathrm{CH}_{3} \mathrm{CH}_{2} \mathrm{OH}+\mathrm{NADP}^{+}$ & [54] \\
\hline
\end{tabular}

\subsection{Pathway}

The production of acetic acid and ethanol from syngas, $\mathrm{CO}, \mathrm{H}_{2}$ and $\mathrm{CO}_{2}$, follows a sequenced set of elementary chemical reactions as seen in Figure 2 [11,55,56]. Each reaction proceeds with an associated enzyme in a specific location within a cell, either free in the cytoplasm, tethered to the surface of the cell membrane or embedded in the membrane. Each cell acts independently, but the combined action of all cells sets conditions in the fermentation bulk liquid. Reactions inside cells are mediated by enzymes (Table 1); each binds specific reactants and converts them to specific products, and these enzymatic reactions are typically reversible. The reactions occur at local conditions of $\mathrm{pH}$ and chemical concentrations inside the cell, conditions that determine the activity of the enzymes and 
the form and availability of reactants. The simple inorganic chemical substrates, $\mathrm{CO}, \mathrm{H}_{2}$ and $\mathrm{CO}_{2}$, are transformed, step by step, first to acetyl-CoA and then to organic products, such as acetic acid and ethanol. Some acetyl-CoA is diverted to form complex organic cell components, carbohydrates, proteins and lipids. However, the majority of gas consumed provides energy for cell function, resulting in the accumulation of acetic acid and ethanol.

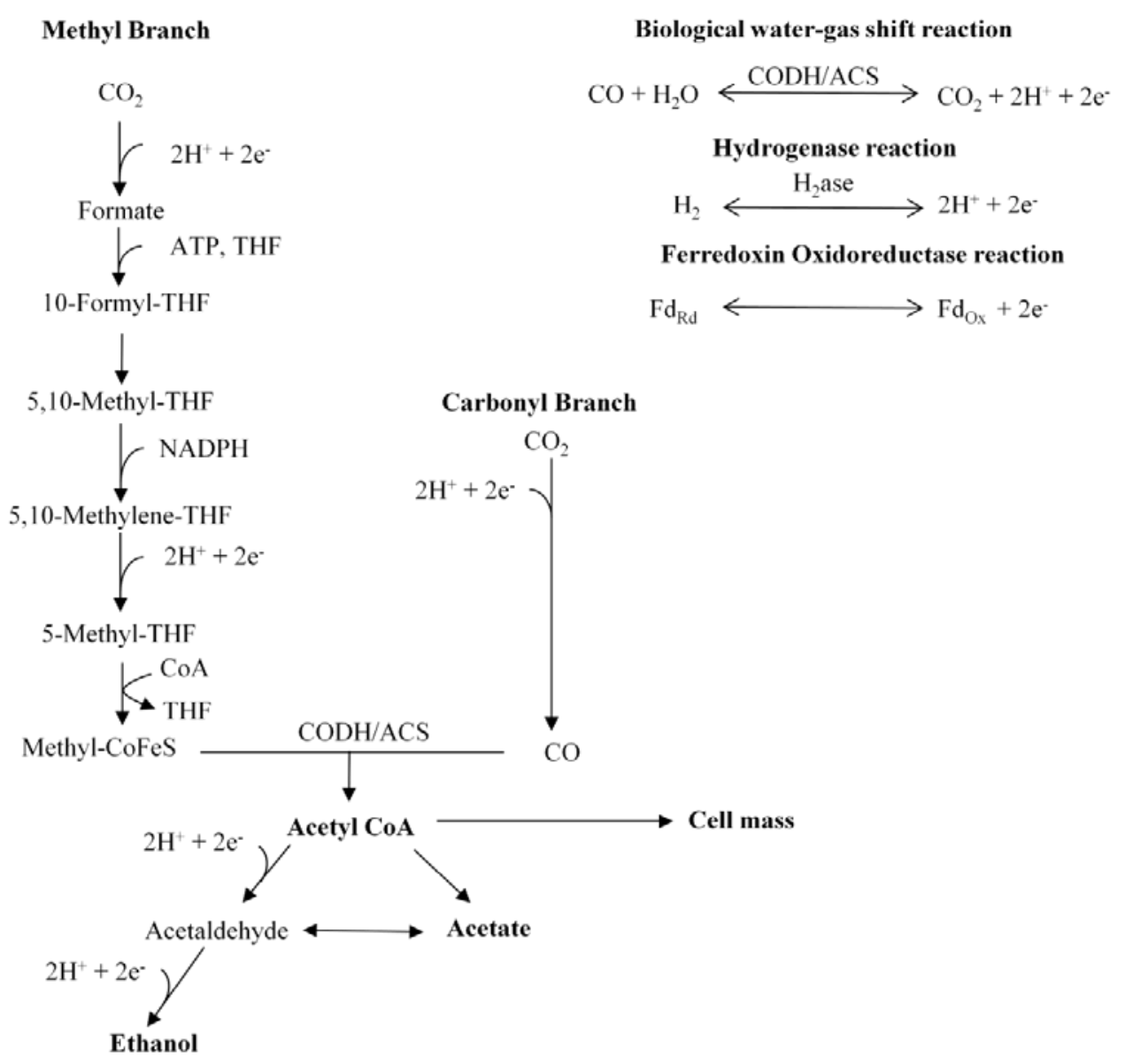

Figure 2. The Wood-Ljungdahl pathway for the production of ethanol and acetic acid; THF: tetrahydrofolate; ACS: acetyl CoA synthase; $\mathrm{CODH}$ : carbon monoxide dehydrogenase; $\mathrm{H}_{2}$ ase: hydrogenase; NADPH: reduced nicotinamide adenine dinucleotide phosphate; adapted from [1,57].

\subsubsection{Stoichiometry}

The production of acetic acid and ethanol from syngas is represented in the literature by the stoichiometry for a single reductant, production from either $\mathrm{CO}$ or $\mathrm{H}_{2}$ with $\mathrm{CO}_{2}$ [2,25,55,58-60]. The pure component stoichiometry and associated Gibbs free energy, $\Delta \mathrm{G}^{\circ}$, are given in Table 2, Equations (1) and (5) for the production of acetic acid and Equations (6) and (12) for the production of ethanol. The similar stoichiometry from $\mathrm{CO}$ and $\mathrm{H}_{2}$ to form products, 4 moles per mole of acetic acid and 6 moles per mole of ethanol, reinforce that $\mathrm{CO}$ and $\mathrm{H}_{2}$ both act as reductants, providing indistinguishable electrons for the subsequent production reactions. $\Delta G^{\circ}$ provides an insight into the direction of a reaction and whether or not it is a spontaneous or not. A negative $\Delta G^{\circ}$ for a reaction means it is spontaneous in the forward direction to make products. A positive $\Delta G^{\circ}$ for a reaction means it is nonspontaneous in the forward direction. When $\Delta \mathrm{G}^{\circ}$ equals zero, a reaction is at equilibrium. $\Delta \mathrm{G}^{\circ}$ is not correlated with the speed of reaction. Kinetics governs the speed of reactions and how fast a product is formed. The $\Delta \mathrm{G}^{\circ}$ values for all reactions in Table 2 are negative and favorable in the formation of acetic acid and ethanol. A more negative $\Delta G^{\circ}$ for a reaction makes that reaction 
more favorable thermodynamically. For example, ethanol production in Equation (6) from only CO is thermodynamically more favorable than in Equations (7) to (12) from both $\mathrm{CO}$ and $\mathrm{H}_{2}$ or from both $\mathrm{H}_{2}$ and $\mathrm{CO}_{2}$. In addition, the higher the molar ratios of $\mathrm{H}_{2}: \mathrm{CO}$, the greater the efficiency of incorporating carbon from $\mathrm{CO}$ into acetic acid or ethanol.

Table 2. Stoichiometry of acetic acid and ethanol production from syngas and change in Gibbs free energy at $298^{\circ} \mathrm{K}$ and $100 \mathrm{kPa}$.

\begin{tabular}{cccc}
\hline Products & Reaction & \multicolumn{2}{c}{$\Delta \mathbf{G}^{\circ} \mathbf{~ k J} / \mathbf{m o l}$} \\
\hline Acetic Acid & $4 \mathrm{CO}+2 \mathrm{H}_{2} \mathrm{O} \rightarrow \mathrm{CH}_{3} \mathrm{COOH}+2 \mathrm{CO}_{2}$ & $(1)$ & -154.6 \\
& $3 \mathrm{CO}+\mathrm{H}_{2}+\mathrm{H}_{2} \mathrm{O} \rightarrow \mathrm{CH}_{3} \mathrm{COOH}+\mathrm{CO}_{2}$ & $(2)$ & -134.5 \\
& $2 \mathrm{CO}+2 \mathrm{H}_{2} \rightarrow \mathrm{CH}_{3} \mathrm{COOH}$ & $(3)$ & -114.5 \\
& $\mathrm{CO}+3 \mathrm{H}_{2}+\mathrm{CO}_{2} \rightarrow \mathrm{CH}_{3} \mathrm{COOH}+\mathrm{H}_{2} \mathrm{O}$ & $(4)$ & -94.4 \\
& $4 \mathrm{H}_{2}+2 \mathrm{CO}_{2} \rightarrow \mathrm{CH}_{3} \mathrm{COOH}+2 \mathrm{H}_{2} \mathrm{O}$ & $(5)$ & -74.3 \\
\hline Ethanol & $6 \mathrm{CO}+3 \mathrm{H}_{2} \mathrm{O} \rightarrow \mathrm{CH}_{3} \mathrm{CH}_{2} \mathrm{OH}+4 \mathrm{CO}_{2}$ & $(6)$ & -217.4 \\
& $5 \mathrm{CO}+\mathrm{H}_{2}+2 \mathrm{H}_{2} \mathrm{O} \rightarrow \mathrm{CH}_{3} \mathrm{CH}_{2} \mathrm{OH}+3 \mathrm{CO}_{2}$ & $(7)$ & -197.3 \\
& $4 \mathrm{CO}+2 \mathrm{H}_{2}+\mathrm{H}_{2} \mathrm{O} \rightarrow \mathrm{CH}_{3} \mathrm{CH}_{2} \mathrm{OH}+2 \mathrm{CO}_{2}$ & $(8)$ & -177.3 \\
& $3 \mathrm{CO}+3 \mathrm{H}_{2} \rightarrow \mathrm{CH}_{3} \mathrm{CH}_{2} \mathrm{OH}+\mathrm{CO} 2$ & $(9)$ & -157.2 \\
& $2 \mathrm{CO}+4 \mathrm{H}_{2} \rightarrow \mathrm{CH}_{3} \mathrm{CH}_{2} \mathrm{OH}+\mathrm{H} \mathrm{O}_{2}$ & $(10)$ & -137.1 \\
& $\mathrm{CO}+5 \mathrm{H}_{2}+\mathrm{CO}_{2} \rightarrow \mathrm{CH}_{3} \mathrm{CH}_{2} \mathrm{OH}+2 \mathrm{H}_{2} \mathrm{O}$ & $(11)$ & -117.1 \\
& $6 \mathrm{H}_{2}+2 \mathrm{CO}_{2} \rightarrow \mathrm{CH}_{3} \mathrm{CH}_{2} \mathrm{OH}+3 \mathrm{H}_{2} \mathrm{O}$ & $(12)$ & -97.0 \\
\hline Acetic Acid & $\mathrm{CO}+\mathrm{CO}_{2}+6 \mathrm{H}^{+}+6 \mathrm{e}^{-} \rightarrow \mathrm{CH}_{3} \mathrm{COOH}+\mathrm{H}_{2} \mathrm{O}$ & $(13)$ & -94.4 \\
Ethanol & $\mathrm{CO}+\mathrm{CO}_{2}+10 \mathrm{H}^{+}+10 \mathrm{e}^{-} \rightarrow \mathrm{CH}_{3} \mathrm{CH} \mathrm{H}_{2} \mathrm{OH}+2 \mathrm{H}_{2} \mathrm{O}$ & $(14)$ & -117.1 \\
\hline
\end{tabular}

Production can proceed using either $\mathrm{CO}$ or $\mathrm{H}_{2}$ [55], but fermentation with syngas, containing $\mathrm{CO}, \mathrm{CO}_{2}$ and $\mathrm{H}_{2}$, typically shows simultaneous uptake of both $\mathrm{CO}$ and $\mathrm{H}_{2}$ [38,41]. Intermediate stoichiometry can be written beginning with production from pure $\mathrm{CO}$ and substituting one $\mathrm{H}_{2}$ for one $\mathrm{CO}$ and reducing consumption of $\mathrm{H}_{2} \mathrm{O}$ and production of $\mathrm{CO}_{2}$ by one for each step. In this way, five balanced equations are obtained showing the "quantum" or molecular production of acetic acid from any combination of four, $\mathrm{CO}$ plus $\mathrm{H}_{2}$, with two carbons fixed in acetic acid. Similarly, seven balanced equations are obtained showing the "quantum" production of ethanol from a combination of six, $\mathrm{CO}$ plus $\mathrm{H}_{2}$, with two carbons fixed in ethanol. The overall stoichiometry observed in fermentation will be the average of the "quantum" stoichiometry; for example, 4.3 moles $\mathrm{CO}$ plus $1.7 \mathrm{moles}_{2}$ can produce 1 mole of ethanol.

The substitution of $\mathrm{H}_{2}$ for $\mathrm{CO}$ as reductant in fixing two carbons in the product, either acetic acid or ethanol, suggests a general stoichiometry independent of the origin of electrons, whether from $\mathrm{CO}$ or $\mathrm{H}_{2}$. Reducing equivalents of $\mathrm{H}_{2}\left(2 \mathrm{H}^{+}+2 \mathrm{e}^{-}\right)$are provided by either $\mathrm{CO}$ or $\mathrm{H}_{2}$, while carbon comes from $\mathrm{CO}$ and $\mathrm{CO}_{2}$. The methyl group of acetic acid is formed from $\mathrm{CO}_{2}$, and the carbonyl is formed from $\mathrm{CO}$. The general stoichiometry of acetic acid formation is given in Equation (13) and the general stoichiometry of ethanol formation in Equation (14). Consumption of four reductants (including CO and $\left.\mathrm{H}_{2}\right)$ and two carbons ( $\mathrm{CO}$ or $\mathrm{CO}_{2}$ including the $\mathrm{CO}$ used as reductant) will produce acetic acid. Consuming six reductants per two carbons will produce ethanol. The energy, $\mathrm{H}^{+}$and $\mathrm{e}^{-}$are supplied by oxidation of $\mathrm{CO}$ or $\mathrm{H}_{2}$, and Equations (15) and (16) describe acetic acid and ethanol production.

$$
\begin{aligned}
\mathrm{CO}+\mathrm{CO}_{2}+\left(\mathrm{nCO}+(3-\mathrm{n}) \mathrm{H}_{2}\right) & \rightarrow \mathrm{CH}_{3} \mathrm{COOH}+\mathrm{nCO}_{2}+(1-\mathrm{n}) \mathrm{H}_{2} \mathrm{O} \\
3 & \geq n \geq-1 \\
\mathrm{CO}+\mathrm{CO}_{2}+\left(\mathrm{n} \mathrm{CO}+(5-\mathrm{n}) \mathrm{H}_{2}\right) & \rightarrow \mathrm{CH}_{3} \mathrm{CH}_{2} \mathrm{OH}+\mathrm{nCO}+(2-\mathrm{n}) \mathrm{H}_{2} \mathrm{O} \\
5 & \geq n \geq-1
\end{aligned}
$$

A negative coefficient for $\mathrm{CO}_{2}$ or $\mathrm{H}_{2} \mathrm{O}$ as a product indicates that the species is added as a reactant. For reactions on a molecular level, $n$ is an integer, and Equations (15) and (16) represent the 
quantum stoichiometry. However, on a molar level of reaction, $n$ is not restricted to integer values, and Equations (15) and (16) represent the average stoichiometry.

\subsubsection{Production Reactions}

The acetyl-CoA pathway has been defined over 70 years of research $[24,56]$ and is shown in Figure 2. Energy and carbon from syngas are used to produce acetyl-CoA. $\mathrm{CO}_{2}$ is converted to a methyl group in the tetrahydrofolate cycle, through a series of reactions that consume one adenosine triphosphate (ATP) and three reducing equivalents of hydrogen $\left(2 \mathrm{H}^{+}+2 \mathrm{e}^{-}\right.$derived from $\left.\mathrm{CO}_{\text {or }} \mathrm{H}_{2}\right)$. Acetic acid can be released from the cell into the bulk liquid (by diffusion or facilitated diffusion) [61] or reduced through acetaldehyde to ethanol consuming another two reducing equivalents [62].

Carbon

Carbon enters the acetyl-CoA pathway reactions as $\mathrm{CO}_{2}$ or $\mathrm{CO} . \mathrm{CO}_{2}$ is required for the formation of formate [46], which is bound to tetrahydrofolate and reduced to form the methyl group of acetyl-CoA. A methyl cation is transferred to acetyl-CoA synthase (ACS) via an enzyme that contains cobalt (and is called the corrinoid iron-sulfur protein or CoFeSP). The carbonyl of acetyl-CoA is derived from $\mathrm{CO}$ bound to carbon monoxide dehydrogenase $(\mathrm{CODH})$, transferred within the bi-functional enzyme to the acetyl-CoA synthase (ACS) active site [63] and condensed with the methyl group and coenzyme A to form acetyl-CoA (Figure 2). Acetyl-CoA is either incorporated in cell components or converted to acetic acid inside the cell, and the conversion of acetyl-CoA to acetic acid via acetyl-phosphate replaces the ATP used to convert $\mathrm{CO}_{2}$ to the methyl cation.

Acetic acid is released by the acetate kinase enzyme to the cytoplasm (inside the cell) and is reduced to ethanol by carboxylic acid reductase [53] and alcohol dehydrogenase using reduced electron carriers like the reduced nicotinamide adenine dinucleotide (NADH) that are not strongly associated with the membrane. The enzymes acetaldehyde dehydrogenase and alcohol dehydrogenase, which are required to reduce acetic acid to ethanol, have been isolated from Moorella thermoacetica (formerly Clostridium thermoaceticum) and Clostridium formicoaceticum [53,54]. Based on commercial acetone-butanol-ethanol (ABE) fermentation, acyl-CoA (acetyl- or butyryl-CoA) is reduced to aldehyde and then to alcohol using low potential electron carriers, at the expense of one ATP. This loss of ATP in equimolar ratio to ethanol production would make ethanol production from syngas impossible. Fraisse [54] and White [53] found that acetic acid is converted directly to acetaldehyde; acetyl-CoA is not the direct precursor of acetaldehyde and ethanol; and ATP is not lost when alcohol is produced. Aldehyde dehydrogenase and alcohol dehydrogenase were also found to be functional for the reduction of other carboxylic acids to their respective alcohols, including reduction of butyric acid to butanol $[30,53,64]$. Ethanol production is affected by the internal electrochemical potential and internal $\mathrm{pH}$ of the cell, which are determined by the concentration of accumulated $\mathrm{CO}$ and $\mathrm{H}_{2}$.

\section{Energy}

During syngas fermentation, energy flows by the transfer of electrons. One pair of electrons $\left(2 \mathrm{e}^{-}\right)$ is supplied for reaction in the cell by each $\mathrm{CO}$ oxidized on $\mathrm{CODH}$ or $\mathrm{H}_{2}$ oxidized on hydrogenase $\left(\mathrm{H}_{2}\right.$ ase); a pair of protons $\left(2 \mathrm{H}^{+}\right)$is released to the cytoplasm for each oxidized $\mathrm{CO}$ [43] or $\mathrm{H}_{2}$ [44]. The electrons are distributed to reaction sites within the cell by electron carriers like ferredoxin and $\mathrm{NAD}(\mathrm{P}) \mathrm{H}$. Electrons from $\mathrm{CODH}$ and $\mathrm{H}_{2}$ ase are first transferred to the membrane-associated clostridial ferredoxin [65] and then are transferred to other electron carriers like NAD(P)H for use in pathway reactions and other cell function. Electrons are transferred via enzymes and cofactors coded in the acetogenic genome in the $R n f$ (for Rhodobacter nitrogen fixing) operon. The $R n f$ operon produces a membrane-bound protein complex that is critical to electron transfer and translocation of protons across the cell membrane [66-68].

The $R n f$ complex is proposed to mediate "electron bifurcation", wherein electrons from $\mathrm{H}_{2}$ are bound on ferredoxin at very low potential using energy supplied from electrons transferred at higher 
potential to NADH. This "bifurcation" is proposed to translocate protons across the cell membrane through the $R n f$ complex proteins. However, electrons from $\mathrm{H}_{2}$ are likely transferred via ferredoxin to the $R n f$ complex, then distributed to $\mathrm{NAD}(\mathrm{P}) \mathrm{H}$ and membrane-integral flavins, equalizing the intracellular potential of all electron carriers. The reduced flavin nucleotides carry protons across the membrane, and the associated electrons, still near the potential of $\mathrm{H}_{2}$, reduce methylene-THF to methyl-THF in a critical reaction of the production pathway. To develop the bifurcation concept, Schuchmann and Muller [69] reported methylene-THF reductase to be neither membrane associated, nor membrane attached. However, Hugenholtz et al. [70] found this critical enzyme was membrane bound, but easily displaced by disruption of the cells for isolation of proteins. The cell membrane serves to insulate the low potential electrons transferred to the flavin and, thus, establish the proton gradient, membrane potential and the proton-motive force used to produce ATP for cell growth.

A single crossover integration in C. ljungdahlii was reported to block the production of "a membrane associated polyferredoxin accepting electrons from ferredoxin and transferring them to membrane domains of the Rnf complex" [68]. Autotrophic growth on $\mathrm{H}_{2}$ and $\mathrm{CO}_{2}$ was blocked by this mutation, and the "proton gradient, membrane potential and protonmotive force collapsed". The reduction of ferredoxin well above its midpoint potential $\left(\mathrm{E}^{\circ \prime}=-420 \mathrm{mV}\right)$ by $\mathrm{H}_{2}$ drives the function of the $R n f$ complex, but the imposed mutation blocked the transfer of electrons from $\mathrm{H}_{2}$ into the $R n f$ complex circuit, and without a supply of energy, the chemical potential across the membrane was dissipated. Presumably, autotrophic growth of the C. ljungdahlii mutant on CO would also have been blocked, although this was not reported by [68]. Insulation of the electron current by the cell membrane is critical to the function of the $R n f$ electron transfer chain that transports $\mathrm{H}^{+}$across the membrane and terminates in reduction of methylene-THF to methyl-THF.

\subsubsection{Key Oxidation/Reduction Reactions in the Acetyl-CoA Pathway}

Electrochemical reactions involve the transfer of electrons and protons. Electrons are transferred from a reduced chemical as it is oxidized to a less reduced (or oxidized) chemical [42,71]. The reduced and oxidized forms of both the electron donor and electron acceptor are called the redox couple. The reaction releasing the oxidized form and electrons, from its reduced form, is called a "half-cell reaction". Important half-cell reactions of the acetyl-CoA pathway are shown in Table 3. Each half-cell reaction (and redox couple) has a mid-point potential (expressed in $\mathrm{mV}$ ) at which the concentrations of the reduced and oxidized forms are equal. $\mathrm{CO}_{2} / \mathrm{CO}$ is a redox couple, and the $\mathrm{CO}_{2} / \mathrm{CO}$ half-cell can be paired with the $\mathrm{H}_{2}$ half-cell; ferredoxin mediates this electron transfer in acetogens [45]. The combined half reactions comprise the water-gas shift reaction, Equation (17); $\mathrm{CO}$ and $\mathrm{H}_{2} \mathrm{O}$ are converted to $\mathrm{H}_{2}$ and $\mathrm{CO}_{2}$ in this reversible reaction.

$$
\mathrm{CO}+\mathrm{H}_{2} \mathrm{O} \leftrightarrow \mathrm{CO}_{2}+\mathrm{H}_{2}
$$

The elementary reactions of the pathway are balanced for charge and conserve elemental species when written as in Figure 2. The chemical equations can be analyzed using pH and chemical concentrations at the enzymes to establish thermodynamic relationships. Several important reactions of the pathway are characterized by paired electrochemical half-cell reactions. The electrons are supplied by the hydrogen $\left(\mathrm{H}^{+} / \mathrm{H}_{2}\right)$ and $\mathrm{CO}_{2} / \mathrm{CO}$ couples. Electrons are distributed to electron carriers such as ferredoxin $\left(\mathrm{Fd}_{\mathrm{Ox}} / \mathrm{Fd}_{\mathrm{Rd}}\right)$ and nicotinamide adenine dinucleotide $\left(\mathrm{NAD}^{+} / \mathrm{NADH}\right)$. In the terminal redox couple $\left(\mathrm{CH}_{3} \mathrm{COOH} / \mathrm{CH}_{3} \mathrm{CH}_{2} \mathrm{OH}\right)$, acetic acid is reduced to ethanol. 
Table 3. Selected half-cell reactions of the acetyl-CoA pathway. $\Delta \mathrm{G}_{\mathrm{r}}{ }^{\circ}$ and $\mathrm{E}^{\circ}$ indicate the standard Gibbs free energy change and midpoint potential of the half-cell reaction at $\mathrm{pH}=0$, while $\Delta \mathrm{G}_{\mathrm{r}}{ }^{\prime}{ }^{\prime}$ and $\mathrm{E}^{\mathrm{o}^{\prime}}$ are at $\mathrm{pH}=7.0, \mathrm{n}_{\mathrm{e}}$ and $\Delta \mathrm{m}_{\mathrm{H}}$ are the numbers of electrons transferred and protons consumed, respectively, and $\Pi_{\text {prod }} / \Pi_{\text {react }}$ is the form of the mass action ratio.

\begin{tabular}{cccccccc}
\hline Half Cell Reduction & $\begin{array}{c}\Delta \mathbf{G}_{\mathbf{r}}{ }^{\circ} \\
\mathbf{( k J / m o l})\end{array}$ & $\begin{array}{c}\mathbf{E}^{\circ} \\
(\mathbf{m V})\end{array}$ & $\mathbf{n}_{\mathbf{e}}$ & $\boldsymbol{\Delta} \mathbf{m}_{\mathbf{H}}$ & $\begin{array}{c}\Delta \mathbf{G}_{\mathbf{r}}{ }^{\prime} \\
\mathbf{( k J / m o l})\end{array}$ & $\begin{array}{c}\mathbf{E}^{\circ^{\prime}} \\
(\mathbf{m V} \mathbf{V})\end{array}$ & $\boldsymbol{\Pi}_{\text {prod }} / \boldsymbol{\Pi}_{\text {react }}$ \\
\hline $2 \mathrm{H}^{+}+2 \mathrm{e}^{-} \leftrightarrow \mathrm{H}_{2(\mathrm{~g})}$ & 0 & 0 & 2 & -2 & 79.90 & -414 & $\mathrm{p}_{\mathrm{H} 2}$ \\
$\mathrm{CO}_{2}+2 \mathrm{H}^{+}+2 \mathrm{e}^{-} \leftrightarrow \mathrm{CO}_{(\mathrm{g})}+\mathrm{H}_{2} \mathrm{O}$ & 20.03 & -104 & 2 & -2 & 99.93 & -518 & $\mathrm{p}_{\mathrm{CO}} / \mathrm{p}_{\mathrm{CO} 2}$ \\
$\mathrm{CH}_{3} \mathrm{COOH}+2 \mathrm{H}^{+}+2 \mathrm{e}^{-} \leftrightarrow \mathrm{CH}_{3} \mathrm{CHO}+\mathrm{H}_{2} \mathrm{O}$ & -7.67 & 40 & 2 & -2 & 72.23 & -374 & $\mathrm{C}_{\mathrm{Ald}} / \mathrm{C}_{\mathrm{HA}}$ \\
$\mathrm{CH}_{3} \mathrm{CHO}+2 \mathrm{H}^{+}+2 \mathrm{e}^{-} \leftrightarrow \mathrm{CH}_{3} \mathrm{CH}_{2} \mathrm{OH}$ & -41.85 & 217 & 2 & -2 & 38.05 & -197 & $\mathrm{C}_{\mathrm{Et}} / \mathrm{C}_{\mathrm{Ald}}$ \\
$\mathrm{NAD}^{+}+\mathrm{H}^{+}+2 \mathrm{e}^{-} \leftrightarrow \mathrm{NADH}^{-}$ & 21.80 & -113 & 2 & -1 & 61.75 & -320 & $\mathrm{C}_{\mathrm{NADH}} / \mathrm{C}_{\mathrm{NAD}+}$ \\
$\mathrm{Fd}_{\mathrm{Ox}}+2 \mathrm{e}^{-} \leftrightarrow \mathrm{Fd}_{\mathrm{Rd}}$ & 81.05 & -420 & 2 & 0 & 81.05 & -420 & $\mathrm{C}_{\mathrm{Fdr}} / \mathrm{C}_{\mathrm{Fdo}}$ \\
\hline
\end{tabular}

\subsection{ATP and Cell Growth}

Autotrophic growth and production are dependent on the transport of protons and electrons across the cell membrane to generate the proton-motive force that drives synthesis of ATP [72]. The proton-motive force consists of a $\mathrm{pH}$ differential plus a difference in electrochemical potential as shown in Equation (18) [42].

$$
\Delta p=\Delta \varphi-\frac{2.3 R T}{F} \Delta p H
$$

where $\Delta p$ is the proton-motive force $(\mathrm{mV})$ driving transfer of protons across the membrane, $\Delta \varphi$ is the potential difference across the membrane $(\mathrm{mV}), \Delta p H$ is the $\mathrm{pH}$ differential across the membrane, $R$ is the gas constant $(8.314 \mathrm{~J} / \mathrm{mol} \mathrm{K}), T$ is the temperature $(\mathrm{K})$ and $F$ is the Faraday constant $\left(96.485 \mathrm{~J} / \mathrm{mV} \mathrm{mol} \mathrm{e}^{-}\right)$.

Protons released into the cytoplasm are consumed in the formation of acetyl-CoA, acetic acid and ethanol, maintaining the charge balance, while one pair of protons $\left(2 \mathrm{H}^{+}\right)$is expelled from the cell for each acetyl-CoA formed. This proton pair is carried across the membrane by a reduced flavin electron carrier, while the electrons are used in the reduction of methylene-THF to methyl-THF [49]. The removal of $\mathrm{H}^{+}$from the interior of the cell develops a differential of $\mathrm{pH}$ and electrochemical potential across the membrane. Protons, as positively-charged particles, are attracted to the more negatively-charged interior of the cell and driven by the higher concentration of protons outside the cell [73]. This proton-motive force pulls protons through an ATP synthase, driving rotation in the ATPase structure that mechanically forms and releases ATP from three binding sites for ATP/ADP $+\mathrm{P}_{\mathrm{i}}$ on the enzyme [74,75]. One ATP is consumed in converting formate to formyl phosphate, and one ATP is recovered in the conversion of acetyl phosphate to acetate. Product formation via the acetyl-CoA pathway yields no net ATP; in syngas fermentation, ATP is obtained only from the chemiosmotic mechanism of the ATP synthase $[73,76]$.

\section{Microbial Conversion of Gas Phase Substrates}

The conversion of $\mathrm{CO}, \mathrm{H}_{2}$ and $\mathrm{CO}_{2}$ by acetogenic bacteria to acetic acid and ethanol via the acetyl-CoA pathway is affected by the conditions inside and outside the cell, as depicted in Figure 3 . These include $\mathrm{pH}$, temperature and concentrations of nutrients, $\mathrm{CO}, \mathrm{H}_{2}$ and $\mathrm{CO}_{2}$, and products like acetic acid and ethanol. Mass transfer also affects the availability of $\mathrm{CO}, \mathrm{H}_{2}$ and $\mathrm{CO}_{2}$ inside the cells, and each intermediate reaction, in vivo, will depend on the concentration of its particular reactants and products. The concentrations of intermediate metabolites define the individual reactions and connect the chain of reactions that constitutes the overall stoichiometry of production. The rate of each reaction in the acetyl-CoA pathway is determined by the concentrations of the metabolites involved and the enzyme kinetics supported in the cell. 
Culture kinetics limits rate of substrate uptake, growth and production.

Mass transfer of $\mathrm{CO}$ and $\mathrm{H}_{2}$ into the cell limits
rate of production and poises thermodynamics.

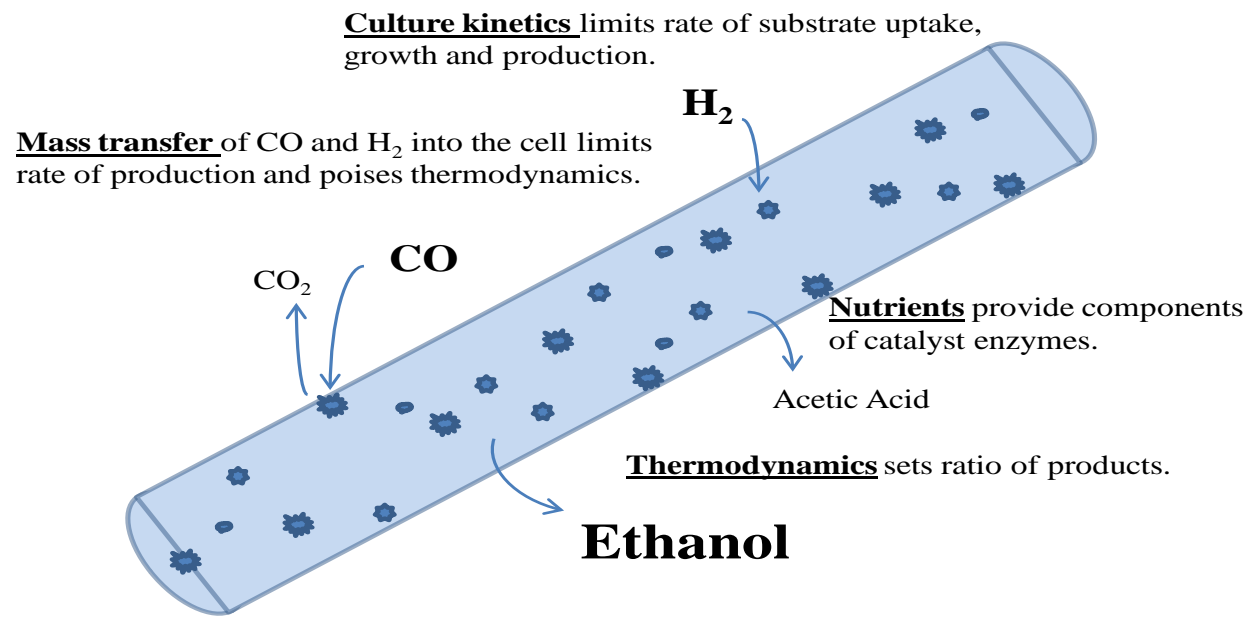

Figure 3. Depiction of an acetogenic bacterial cell showing the supply of $\mathrm{CO}$ and $\mathrm{H}_{2}$ into the cell and efflux of $\mathrm{CO}_{2}$ by mass transfer, the reaction on enzymes dependent on nutrients taken from the medium to support culture kinetics of growth and production and the thermodynamic determination of products in syngas fermentation.

\subsection{Gas Solubility}

$\mathrm{CO}$ and $\mathrm{H}_{2}$ are sparingly soluble in water, and their solubility depends on the partial pressure of the individual species according to Henry's law. As an example, for CO:

$$
C_{C O}=y_{C O} P_{T} / H_{C O}
$$

where $C_{\mathrm{CO}}$ is the liquid phase concentration of $\mathrm{CO}, y_{\mathrm{CO}}$ is the gas phase mol fraction of $\mathrm{CO}, P_{T}$ is the total pressure and $H_{C O}$ is the Henry's law constant for $\mathrm{CO}$. The Henry's law constants for $\mathrm{CO}, \mathrm{H}_{2}$ and $\mathrm{CO}_{2}$ at $37^{\circ} \mathrm{C}$ are given in Table 4. Saturated concentration of either $\mathrm{CO}$ or $\mathrm{H}_{2}$ in water under $100 \mathrm{kPa}$ of pure gas is less than $10^{-3} \mathrm{~mol} / \mathrm{L}$. $\mathrm{CO}$ and $\mathrm{H}_{2}$ must be continuously replenished in the liquid medium to support active fermentation. The lowest concentrations of $\mathrm{CO}$ and $\mathrm{H}_{2}$ are inside the cell where the enzymes that catalyze oxidation reside. In contrast, $\mathrm{CO}_{2}$ is produced in fermentation that consumes $\mathrm{CO}$, and in that case, $\mathrm{CO}_{2}$ is transferred from inside the cell through the liquid phase to the gas phase. The concentration of $\mathrm{CO}_{2}$ will be highest inside the cell.

Table 4. Henry's law constants and diffusivities for gases in water at $37^{\circ} \mathrm{C}$ a.

\begin{tabular}{ccc}
\hline Gas & $\boldsymbol{H}(\mathbf{k P a ~ L / m o l})$ & $\boldsymbol{D}_{\boldsymbol{i}, \boldsymbol{W}}\left(\mathbf{m}^{\mathbf{2}} \mathbf{s}\right)$ \\
\hline $\mathrm{CO}$ & 121,561 & $2.50 \times 10^{-9}$ \\
$\mathrm{H}_{2}$ & 140,262 & $6.24 \times 10^{-9}$ \\
$\mathrm{CO}_{2}$ & 4240 & $2.69 \times 10^{-9}$ \\
$\mathrm{O}_{2}$ & 101,300 & $3.25 \times 10^{-9}$ \\
\hline \multicolumn{3}{c}{ a Adapted from [77]. }
\end{tabular}

\subsection{Transport Theory}

The low solubility of $\mathrm{CO}$ and $\mathrm{H}_{2}$, gases that provide the energy for syngas fermentation and energy conserved in ethanol product, requires these gases to be continually replenished in the fermentation broth to sustain production. The rate of mass transfer of substrate gas from the bulk gas through the gas-liquid interface and the bulk liquid into the cell, depicted in Figure 4, can be described by film theory [78]. 


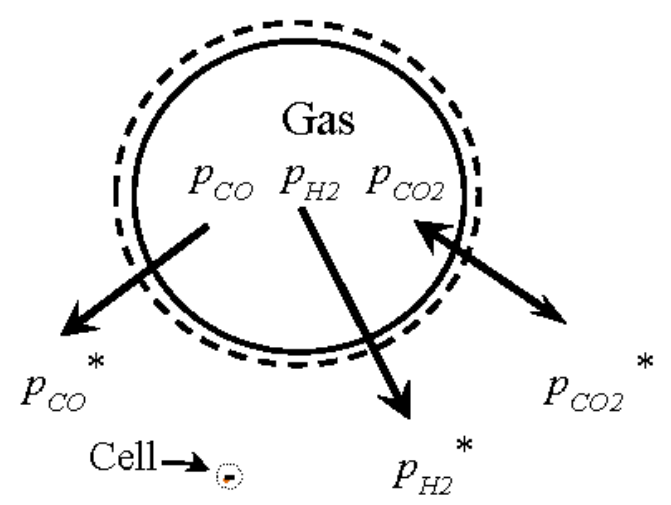

Figure 4. Schematic of gas to liquid mass transfer in the fermentation broth. Partial pressure in the gas phase, $p_{\mathrm{CO}}, p_{\mathrm{H} 2}, p_{\mathrm{CO} 2}$ and in the equilibrium bulk liquid phase pressure, $p_{\mathrm{CO}}{ }^{*}, p_{\mathrm{H} 2}{ }^{*}, p_{\mathrm{CO} 2}{ }^{*}$. The bubble boundary is indicated by the solid line and the liquid film by the dashed line; a single cell is indicated inside the small circle; the scale of the bubble is $1 \mathrm{~mm}$ in diameter; the size of the cell is $0.5 \mu \mathrm{m}$ in diameter by $3 \mu \mathrm{m}$ long; there are more than $10^{10}$ cells per liter of fermentation broth.

Diffusion of gas components within the bulk gas is very fast relative to the consumption rate, and the concentration of each species is uniform throughout the gas phase. The concentration of each species in the liquid at the interface is at equilibrium with the bulk gas partial pressure as predicted by Henry's law. The liquid at the interface is part of a stagnant film of fluid through which dissolved gas must transfer by diffusion to the bulk liquid, and since diffusion is driven by the concentration difference, the transfer rate is dependent on the gas diffusivity through water and the thickness of the stagnant film. Outside of the stagnant film, the liquid is assumed to be mobile and turbulent [79], and dissolved gas transfer within the bulk liquid is by bulk flow at rates far exceeding diffusion. The bulk liquid is assumed to be well mixed and homogeneous.

Gas is transferred into the cell by a diffusion process through the cell membrane, which is 6 to $9 \mathrm{~nm}$ thick [80]. C. ragsdalei cells are rod shaped with typical dimension of $0.5 \mu \mathrm{m}$ by $3 \mu \mathrm{m}$, and even at low cell density $(0.02 \mathrm{~g}$ cells $/ \mathrm{L})$, there are more than $10^{10}$ cells $/ \mathrm{L}$ of bulk liquid. The surface area of these cells will exceed the area of the gas-liquid interface by up to three orders of magnitude in a typical fermentation, and resistance to gas transfer across the membrane will be negligible. The gas to liquid mass transfer rate is controlled by diffusion through the film of stagnant liquid at the gas-liquid interface, and the rate of molar gas transfer is proportional to the difference in concentration from the surface of the liquid to the bulk liquid.

The partial pressure of each component in the gas phase is the product of its mole fraction and the total pressure. The partial pressure for $\mathrm{CO}$ is calculated by Equation (20).

$$
p_{\mathrm{CO}}=y_{\mathrm{CO}} P_{T}
$$

The liquid film mass transfer of $\mathrm{CO}$ is represented by Equation (21).

$$
-\frac{1}{V_{L}} \frac{d n_{C O}}{d t}=\frac{k_{L, C O} a}{V_{L}}\left(c_{C O}^{*}-c_{C O, L}\right)=\frac{\left(\frac{k_{L, C O} a}{V_{L}}\right)}{H_{C O}}\left(p_{C O}-p_{C O}^{*}\right)
$$

where $c^{*} \mathrm{CO}$ is the concentration of $\mathrm{CO}$ at the gas-liquid interface in equilibrium by Henry's law; $c_{C O, L}$ is the concentration of $\mathrm{CO}$ in the bulk liquid; $p_{\mathrm{CO}}{ }^{*}$ is the $\mathrm{CO}$ partial pressure $(\mathrm{kPa})$ in equilibrium by Henry's law with the concentration of $C O$ dissolved in the bulk liquid; $p_{C O}$ is partial pressure in the gas bubble; $H_{C O}$ is the Henry's law constant for $\mathrm{CO}(\mathrm{kPa} \mathrm{L} / \mathrm{mol})$; and $V_{L}$ is the volume (L) of liquid into which gas is transferred. The molar rate of $\mathrm{CO}$ transfer is $-d n_{\mathrm{CO}} / d t(\mathrm{~mol} \mathrm{CO} / \mathrm{h})$, where the negative sign denotes consumption from $n_{\mathrm{CO}}$ moles of $\mathrm{CO}$ in the bulk gas. The constant of proportionality is 
$k_{L, C O} a / V_{L}$, which is the overall liquid film mass transfer coefficient (often denoted simply as $k_{L} a$ in the literature) for $\mathrm{CO}$ with units of reciprocal time $\left(\mathrm{h}^{-1}\right)$. The area of the gas/liquid interface is $a\left(\mathrm{~m}^{2}\right)$. The term $k_{L, C O}$ is the liquid film mass transfer coefficient for $\mathrm{CO}\left(\mathrm{L} / \mathrm{m}^{2} \mathrm{~h}\right)$, which includes the effects of turbulence in the liquid, hydrodynamic conditions like viscosity that affect film thickness and gas diffusivity in the aqueous phase. When $\mathrm{CO}$ is mass transfer limited, $p_{C O}{ }^{*}$ is arithmetically zero, and $k_{L, C O} a / V_{L}$ can be calculated from $d n_{C O} / d t$ and $p_{C O}$ using Equation (21).

The volumetric mass transfer coefficients for $\mathrm{H}_{2}\left(k_{L, H 2} a / V_{L}\right)$ and $\mathrm{CO}_{2}\left(k_{L, C O 2} a / V_{L}\right)$ differ from $k_{L, \mathrm{CO}} a / V_{L}$, but are proportional. The area of the gas/liquid interface and the liquid volume are the same for all gases, as is the intensity of turbulence in the liquid. The coefficients for these gases will differ due to their diffusivity in the fermentation broth $\left(D_{i, W}\right)$ through the liquid film, and the measured $k_{L, \mathrm{CO}} a / V_{L}$ from Equation (21) is used to predict values of $k_{L, \mathrm{H} 2} a / V_{L}$ and $k_{L, \mathrm{CO} 2} a / V_{L}$ based on the surface renewal theory for film transfer [81].

$$
\frac{k_{L, C O} a}{V_{L}}=\sqrt{\frac{D_{\mathrm{CO}, W}}{D_{H 2, W}}}\left(\frac{k_{L, H 2} a}{V_{L}}\right)=\sqrt{\frac{D_{\mathrm{CO}, W}}{D_{\mathrm{CO} 2, \mathrm{~W}}}}\left(\frac{k_{L, C O 2} a}{V_{L}}\right)
$$

The actual capacity of the fermenter to transfer $\mathrm{H}_{2}$ and $\mathrm{CO}_{2}$ is represented in $k_{L, H 2} a / V_{L}$ and $k_{L, \mathrm{CO} 2} a / V_{L}$ determined from Equation (22). This capacity can remain unused, in which case $\mathrm{H}_{2}$ or $\mathrm{CO}_{2}$ will accumulate in the bulk liquid and in the cell up to saturation of the dissolved gas. The fermentation broth was assumed to be like water, which is $98 \%$ of the medium.

The attainment of higher mass transfer represented in the volumetric mass transfer coefficients, $k_{L, C O} a / V_{L}$ and $k_{L, H 2} a / V_{L}$, is of primary concern in most discussion of syngas fermentation [82-84]. A model of syngas fermentation in the continuously-stirred tank reactor (CSTR) was developed to assess the potential for the production of acetate [85], and mass transfer has been studied in various configurations of fermenters $[82,83,86,87]$. Klasson et al. [83], however, notes that the rate of mass transfer will not exceed the rate of reaction of the slightly soluble substrates and that the applied mass transfer should balance the supply and consumption of $\mathrm{CO}$ and $\mathrm{H}_{2}$.

\subsection{Enzyme Catalyzed Reactions}

Conversion of $\mathrm{CO}$ and $\mathrm{H}_{2}$ to acetic acid, ethanol and cell mass is performed on a platform of enzymes contained in the cells (Figure 3 and Table 1). The cell membrane separates the cytoplasm from the bulk liquid fermentation broth, and enzymes are either suspended in the cytoplasm or associated with or embedded in the membrane. Intracellular conditions of $\mathrm{pH}$, oxidation reduction potential (ORP) and chemical composition are related to the bulk liquid by diffusion and membrane transport and can differ in significant ways that are essential to cell function $[42,88]$. The concentrations of dissolved $\mathrm{CO}, \mathrm{H}_{2}$ and $\mathrm{CO}_{2}$ inside the cells are nearly the same (within $5 \%$ ) as the bulk liquid, since the transfer of gas into the cells occurs along a short mass transfer path through a very thin membrane (6 to $9 \mathrm{~nm}$ ) with a large total surface area. The observed rates of consumption of gas and the formation of products in the defined stoichiometry of the production pathway reveal the mass flux of carbon, protons and electrons through the pathway reactions. However, in analogy to the catalytic conversion of syngas to ethanol, production is, "impacted by kinetic and thermodynamic constraints." as previously reported [15]. The dissolved gas concentrations set the thermodynamics of reactions, set the concentrations of intermediate metabolites and determine the kinetic rates. Fermentation occurs in this intracellular environment, and the mass flux through the biological pathways can be quantified and controlled to achieve targeted results on the macroscopic scale.

\subsection{Thermodynamics}

Syngas fermentation thermodynamics have been examined [89] using transformed thermodynamics, and it was concluded that $\mathrm{CO}$ was always preferred over $\mathrm{H}_{2}$ as a substrate for fermentation. $\mathrm{CO}$ inhibition of hydrogenase or thermodynamic disfavor was suggested as the reason for low and 
delayed uptake of $\mathrm{H}_{2}$ in syngas fermentation. These thermodynamic calculations assumed bulk liquid concentration saturated from the gas phase partial pressures of $\mathrm{H}_{2}, \mathrm{CO}$ and $\mathrm{CO}_{2}$. While acetogenic fermentation of gas containing both $\mathrm{CO}$ and $\mathrm{H}_{2}$ can exhibit periods of exclusive $\mathrm{CO}$ uptake, $\mathrm{CO}$ and $\mathrm{H}_{2}$ are typically consumed together [41], and the concentrations of dissolved $\mathrm{CO}$ and $\mathrm{H}_{2}$ are changed significantly to effect mass transfer.

The ordered chemical reactions in the acetyl-CoA pathway occur in sequence to produce acetyl-CoA, acetic acid and ethanol from $\mathrm{CO}_{2}, \mathrm{CO}$ and $\mathrm{H}_{2}$. Each reaction is mediated by an enzyme that catalyzes the reaction, and each reaction proceeds in the direction of favored thermodynamics, for which $\Delta G_{r}<0$. The thermodynamics of biological reactions are addressed in biochemistry texts $[88,90]$ and reviews [66,71]; these treatments discuss the criteria for a reaction to proceed, $\Delta G_{r}<0$, and for thermodynamic equilibrium, $\Delta G_{r}=0$, and the dependence of $\Delta G_{r}$ on concentration of reactants and products through the mass action ratio [88]. The effect of $\mathrm{pH}$ on $\Delta G$ is not discussed extensively, although Lehninger (1982) stated, "Biochemical reactions take place near $\mathrm{pH} 7.0$ and often involve $\mathrm{H}^{+\prime \prime}$ to introduce the standard free energy at $\mathrm{pH} 7.0, \Delta G_{r}{ }^{\circ}$. The dependence of $\Delta G_{r}$ on $\mathrm{pH}$ and the application in redox reactions in the cell are discussed in Cramer and Knaff [42]. Thermodynamic Cramer and Knaff data for reactions and compounds of interest in biological systems are available in the appendix of Thauer et al. [71], and these data can be used to define the thermodynamic position of the reactions of the acetyl-CoA pathway. Cramer and Knaff [42] emphasized the division of the intracellular space, where the enzymes reside, from the bulk liquid in fermentation. The production reactions occur inside the cell, while measurements like $\mathrm{pH}$ and ORP are taken in the bulk liquid. Fermentation thermodynamics are characterized by parameters that cannot be measured directly, and such parameters must then be inferred by calculation from available measurements. These calculations require assumptions informed by the biochemical mechanisms to build the equations for data analysis and a predictive model of fermentation.

\subsection{Electrochemistry}

Many reactions in the acetyl-CoA pathway are oxidation-reduction reactions, in which electrons are transferred from one molecule to another. Electron donors are oxidized, and the electron acceptors are reduced. In the water-gas shift reaction in Equation (17), $\mathrm{CO}$ is oxidized to $\mathrm{CO}_{2}$, and $\mathrm{H}^{+}$is reduced to $\mathrm{H}_{2}$. The two half-reactions are shown in Equations (23) and (24).

$$
\begin{gathered}
\mathrm{CO}+\mathrm{H}_{2} \mathrm{O} \leftrightarrow \mathrm{CO}_{2}+2 \mathrm{H}^{+}+2 \mathrm{e}^{-} \\
2 \mathrm{H}^{+}+2 \mathrm{e}^{-} \leftrightarrow \mathrm{H}_{2}
\end{gathered}
$$

$\mathrm{CO}$ donates $2 \mathrm{e}^{-}$that are used to produce $\mathrm{H}_{2}$. The water-gas shift reaction is reversible, and $\mathrm{H}_{2}$ can be oxidized to produce $\mathrm{CO}$ from $\mathrm{CO}_{2}$. Reaction proceeds in the direction for which $\Delta G_{r}<0$. The reaction is in equilibrium when $\Delta G_{r}=0$.

The oxidized and reduced forms of a chemical comprise a redox couple, for example $\mathrm{H}_{2} / \mathrm{H}^{+}$and $\mathrm{CO} / \mathrm{CO}_{2}$. The oxidized form accepts electrons (and sometimes $\mathrm{H}^{+}$) and becomes reduced. When the half-reaction is set at the standard conditions of $1.0 \mathrm{~mol} / \mathrm{L}$ reactants and products, the redox couple exhibits a characteristic tendency or potential to donate electrons. This potential, measured in volts, with equal concentrations of the oxidized and reduced forms, is the midpoint potential. This is referred to as $\mathrm{E}^{\circ}$ at $\mathrm{pH} 0 . \mathrm{E}^{\circ}$ for a half-cell reaction can be calculated from $\Delta G_{r}{ }^{\circ}$ as in Equation $(25)[71,88]$.

$$
E^{\circ}=-\Delta G_{r}^{o} / n_{e} F
$$

where $n_{e}$ is the number of electrons transferred and $F$ is the Faraday constant $\left(0.0965 \mathrm{~kJ} / \mathrm{mV} \mathrm{mol} \mathrm{e}^{-}\right)$. Note that this potential is a characteristic of the half-cell reaction, not a differential. The Gibbs free energy change for a half-cell reaction, $\Delta G_{r}$, changes with concentrations of products and reactants; 
the electrochemical potential of the half-cell changes, as well. The potential (E) is given by the Nernst equation $[80,88]$.

$$
E=-\frac{\Delta G_{r}}{n_{e} F}=E^{o}-\frac{R T}{n_{e} F} \ln \left(\prod C_{(\text {Products })} / \prod C_{(\text {Reactants })}\right)+2.302 \frac{R T}{n_{e} F} \Delta m_{H} p H
$$

The notation ( $\left.\Pi C_{\text {Products }} / \Pi C_{\text {Reactants }}\right)$ represents the mass action ratio for the reaction [88], and $\Delta m_{H}$ is the number of protons produced in the reaction. $E$ is the potential of the redox couple to donate electrons under the actual conditions, and each redox couple exhibits its characteristic potential under those conditions. A redox couple at lower potential (more negative) donates electrons (is oxidized) to couples at higher potential. Two half-cell reactions like Equations (23) and (24) are combined, an oxidation with a reduction, in a balanced reaction, as shown in the water-gas shift reaction in Equation (17). When the reaction reaches equilibrium, $\Delta G_{r}=0$, and both redox couples are at the same potential $E$. The degree of reduction of each couple is reflected in the mass action ratio that gives $E$ for the half-cell in Equation (26).

\subsection{Electron Carriers}

Bar-Even [91] asks, "Does acetogenesis require especially low reduction potential?" and applies similar thermodynamic analysis under the bifurcation concept. Bar-Even acknowledges lower concentrations of reactants in syngas fermentation reactions, but does not recognize the very low dissolved gas concentrations (particularly for $\mathrm{CO}$ ) that produce mass transfer driving force in syngas fermentation. When mass transfer is rate limiting, the transfer of gas to the cell is the slowest process in the fermentation, and all reaction steps in the production pathway are fast relative to the rate of gas supply. Under mass transfer limitation, the reactions of the production pathway approach thermodynamic equilibrium, and all electrochemical half-cell reactions inside the cell approach the same potential, $\mathrm{E}_{\mathrm{Cell}}$. The assumption of thermodynamic equilibrium at one intracellular potential sets a boundary condition that defines the thermodynamic state of the pathway reactions. The approach to this assumed thermodynamic reaction state provides a convenient method to describe the reaction set for study and modeling of syngas fermentation.

The potential of the oxidation-reduction reactions of the pathway can be estimated by Equation (26) using $E^{\circ}$ calculated from Equation (25). Then, Equation (26) can be rearranged to calculate the mass action ratio as in Equation (27).

$$
\left(\prod C_{(\text {Products })} / \prod C_{(\text {Reactants })}\right)=\exp \left[-\frac{\Delta G_{r}^{o}}{R T}-\frac{n_{e} F E}{R T}+2.302 \Delta m_{H} p H\right]
$$

Mass action ratios for selected half-cell reactions from the Wood-Ljungdahl pathway are presented in Table 3. Note that the ratios of products to reactants are the ratios of concentrations or partial pressures, except for the partial pressure of $\mathrm{H}_{2}$. The half-cells are typically two electron reductions, $n_{e}=2$, and that most reductions consume two protons, $\Delta m_{H}=-2$, except $\mathrm{NADH} / \mathrm{NAD}^{+}$and $\mathrm{Fd}_{\mathrm{r}} / \mathrm{Fd}_{\mathrm{o}}$ consume one proton and no protons, respectively. The values of $\Delta G^{\circ \prime}$ and $\mathrm{E}^{\circ \prime}$ given in Table 3 are calculated at $\mathrm{pH} 7.0$ and match values given by Thauer et al. [71].

The electrochemical couples are defined by the mass action ratio of products to reactants in the half-cells at a given $\mathrm{pH}$. The $\mathrm{CO} / \mathrm{CO}_{2}$ half-cell is defined by $p_{\mathrm{CO}}{ }^{*} / p_{\mathrm{CO}}{ }^{*}$, while the $\mathrm{H}_{2}$ half-cell is defined by $p_{\mathrm{H} 2}{ }^{*}$ alone. The calculated $p_{\mathrm{H} 2}{ }^{*}$ defines the potential at a given $\mathrm{pH}$ and is the best measure of the internal electrochemical potential, $E_{C e l l}$, that sets the ratio of ethanol to acetic acid attained. Equation (27) correlates the concentrations of chemicals inside the cell to the intracellular $\mathrm{pH}\left(\mathrm{pH}_{i c}\right)$ and $\mathrm{E}_{\mathrm{Cell}}$. 


\subsection{Kinetics}

Thermodynamics control the direction and possible extent of the reactions in the production pathway, while kinetics describes the rates of reactions and the overall rates of $\mathrm{CO}$ and $\mathrm{H}_{2}$ consumption, acetic acid and ethanol accumulation, as well as cell growth. The overall rates are expected to be proportional to cell mass $\left(X V_{L}\right)$ in the fermenter, with the coefficient of proportionality being the specific growth rate $(\mu)$ for growth and the specific uptake rate ( $q_{\mathrm{CO}}$ for $\mathrm{CO}$ and $q_{\mathrm{H} 2}$ for $\mathrm{H}_{2}$ ). Individual reaction rates are related to the concentrations of the reactants and products using a kinetic model, such as Michaelis-Menten for enzyme-mediated reactions [92]. The specific growth and specific uptake rates are likewise correlated to the concentration of substrates, like $\mathrm{CO}$ and $\mathrm{H}_{2}$ inside the cell, in a kinetic model, such as the Monod equation [92,93]. The concentrations of substrates and products that are important in syngas fermentation are the $\mathrm{CO}, \mathrm{H}_{2}, \mathrm{CO}_{2}$, acetic acid and ethanol dissolved in the bulk liquid. These concentrations are likewise thermodynamic quantities that can be measured or predicted. The dissolved $\mathrm{CO}, \mathrm{H}_{2}$ and $\mathrm{CO}_{2}$ are represented by the dissolved partial pressures, $p_{\mathrm{CO}}{ }^{*}, p_{\mathrm{H} 2}{ }^{*}$ and $p_{\mathrm{CO} 2}{ }^{*}$, and these can be calculated from mass transfer analysis of the experimentally-observed uptake.

Description of fermentation kinetics incorporates time differentials of measured parameters that describe the cell culture. The specific growth rate is the production of cell mass per unit of cell mass per time, $\mathrm{g}_{x} / \mathrm{g}_{\mathrm{x}} \mathrm{h}$ or in $\mathrm{h}^{-1}$, and calculated as:

$$
\mu=\frac{1}{X} \frac{\mathrm{d} X}{\mathrm{dt}}
$$

where $X$ is the cell mass concentration, in $\mathrm{g} / \mathrm{L}$. The specific uptake of $\mathrm{CO}\left(q_{\mathrm{CO}}\right)$ or $\mathrm{H}_{2}\left(q_{\mathrm{H} 2}\right)$ is the consumption of the gas per unit cell mass per time, $\mathrm{mol} / \mathrm{g}_{\mathrm{x}} \cdot \mathrm{h}$, which is estimated as:

$$
\begin{aligned}
q_{C O} & =\frac{1}{X V_{L}} \frac{d n_{C O}}{d t} \\
q_{H 2} & =\frac{1}{X V_{L}} \frac{d n_{H 2}}{d t} \\
q_{C O+H 2} & =\frac{1}{X V_{L}} \frac{d n_{C O+H 2}}{d t}
\end{aligned}
$$

Syngas fermentation by autotrophic acetogens produces complex chemicals including proteins, sugars, nucleic acids and lipids from $\mathrm{CO}$ and $\mathrm{H}_{2}$. This progression from small to complex must occur through a reversal of reactions typical in sugar fermentation; acetyl-CoA to pyruvate to retrace the glycolytic pathways and branches that produce amino acids [94]. Most reactions of the autotrophic pathway operate near thermodynamic equilibrium. Reaction rates depend on the dissolved concentrations of $\mathrm{CO}, \mathrm{H}_{2}$ and $\mathrm{CO}_{2}$, and prominent redox reactions used in the pathway dispose syngas fermentation to inhibitions and competition of substrates for enzyme binding sites. Moreover, the production reactions are reversible, and the production rate depends on product concentrations. An effective model of syngas fermentation should include the prediction of reaction rates using the same intracellular potential, $\mathrm{pH}$ and concentrations of $\mathrm{CO}, \mathrm{H}_{2}$ and $\mathrm{CO}_{2}$ that define the thermodynamics.

\subsection{Conceptual Model of Fermentation}

The initial description of syngas fermentation borrowed from the phenomenological description of the ABE (acetone-butanol-ethanol) fermentation that was commercially prominent in the last century $[59,95,96]$. This concept of alcohol production persists in the basis of ongoing research $[3,11]$ and is the basis for organism development through genetic modification [97]. Ramió-Pujol et al. [3] notes, "successful production of alcohols in clostridia relies on the metabolic shift from acido-genesis (production of acids) to solventogenesis (production of alcohols). The mechanisms governing this 
shift have been extensively investigated, especially in acetone-butanol-ethanol (ABE) fermenting clostridia." However, "little is known about the regulatory circuits and molecular mechanisms for the transition to the solventogenesis". It is appropriate that the study of syngas fermentation might lend knowledge to better understand the ABE fermentation.

Syngas fermentation has been modeled by correlating cell growth and productivity with the partial pressure of $\mathrm{CO}$ in the gas phase $[58,98]$. However, the isolated focus on the $\mathrm{CO}$ concentration in the supply gas ignores both the presence of $\mathrm{H}_{2}$ and $\mathrm{CO}_{2}$ in the fermentation reactions and the difference in concentration imposed by the transfer of each gas into the liquid phase. Growth of C. ljungdahlii on $\mathrm{H}_{2} / \mathrm{CO}_{2}$ shows $\mathrm{H}_{2}$ to be a competent source of energy for growth and production in syngas fermentation [55]. The requirement for $\mathrm{CO}_{2}$ as carbon entering the methyl branch of the acetyl-CoA pathway in Figure 2 shows the importance of the $\mathrm{CO}_{2}$ concentration in the production of acetyl-CoA and subsequent synthesis of acetic acid, ethanol and cell mass. Further, $\mathrm{CO}$ and $\mathrm{H}_{2}$ are used together in syngas fermentation, and both provide electrons to the fermentation reactions [41]. A single parameter model of syngas fermentation using $\mathrm{CO}$ partial pressure in the bulk gas is not adequate. Chen et al. [93] prepared an ambitious model to describe syngas fermentation through the space of a bubble column fermenter. However, appropriate data to populate the model constants were lacking. The model does not apply the chemical engineering unit operations with appropriate assumptions to derive rigorous thermodynamic and kinetic parameters for the equations. The model utility can be improved by applying these engineering techniques.

We propose a new conceptual model of syngas fermentation that includes the growth of acetogens with concurrent ethanol production and high conversion of $\mathrm{CO}$ and $\mathrm{H}_{2}$, reduced dissolved concentration of sparingly soluble $\mathrm{CO}$ and $\mathrm{H}_{2}$ resulting from high rate of gas transfer to the intracellular enzymes, less inhibition of the hydrogenase enzyme at very low dissolved concentration of $\mathrm{CO}$ and de facto mass transfer limitation for $\mathrm{CO}$ in active syngas fermentation. Further, concurrent uptake of $\mathrm{CO}$ and $\mathrm{H}_{2}$ with electron flow from both species to reduce ferredoxin establishes the thermodynamic equilibrium of the water-gas shift within the cell, and the reduction of acetic acid to ethanol in redox reactions, coupled to oxidation of $\mathrm{CO}$ and $\mathrm{H}_{2}$ via cellular electron carriers, suggests a single intracellular redox potential $\left(\mathrm{E}_{\mathrm{Cell}}\right)$ and $\mathrm{pH}\left(\mathrm{pH}_{i c}\right)$. The redox reactions of the acetyl-CoA pathway shown in Figure 2 operate near thermodynamic equilibrium at $E_{C e l l}$ and $p H_{i c}$. A mathematical model constructed with equations conforming to this novel conceptual model describes observed fermentation behaviors and has proven useful in fermentation analysis and control [99].

\subsection{Reactor Design}

Serum bottles are useful for culture maintenance, but the inherent batch operation is marked by transient conditions of substrate supply and cell and product concentrations. The baffled CSTR (continuously-stirred tank reactor) fermenter equipped with gas dispersion impellers can be operated in semi-batch mode with batch liquid and continuous gas feed, with fed-batch liquid, or with both continuous gas and liquid feed. Two-stage CSTR fermenters have been operated with the first CSTR configured to promote growth of the acetogenic culture with acid production and the second CSTR operated at low $\mathrm{pH}$ under nutrient limitation and low gas conversion to achieve high ethanol concentration [100]. Column fermenters that show promise include a bubble column with a ceramic monolith to support biofilm [84], a trickle bed with biofilm [87,101,102] and a biofilm supported on a hollow fiber membrane for gas dispersion [86,87]. Biofilms retain cells, but long-term mass transfer and fouling may limit application. Ethanol productivity was reported to increase in a two-stage CSTR and bubble column with gas and cell recycling because more cells can be accumulated and more gas can be processed in two-stage bioreactors [103]. Chen et al. [93] developed differential equations to describe syngas fermentation through a bubble column, but as yet lack appropriate data for modeling and validation. Column fermenters can be modeled as a series of CSTR, and each CSTR stage can be characterized and designed to deliver mass transfer appropriate to meet a portion of the goals for overall fermentation. 
Fermenter equipment can be designed using computer simulation models to meet the requirements for commercial fermentation. Syngas fermentation should be performed with continuous feed of syngas and liquid medium and removal of product for uninterrupted production. Continuous operation must provide high conservation of energy from the syngas into ethanol, a high concentration of ethanol and stable operation without shutdown over long periods. High energy conservation is only achieved through high conversion of both $\mathrm{CO}$ and $\mathrm{H}_{2}$, as well as high specificity for ethanol as the exclusive product. High concentrations of $\mathrm{CO}$ and $\mathrm{H}_{2}$ promote a high ethanol concentration relative to acetic acid. Stable operation that maintains a steady state marked by high activity of the bacterial culture for $\mathrm{CO}$ and $\mathrm{H}_{2}$ uptake is promoted by tight process control and equipment designed for mechanical reliability, redundancy and ease of maintenance.

The typical laboratory CSTR operates with plug flow characteristic for gas conversion, but achieves a single aggregate state of the fermentation parameters in the well-mixed liquid. Since the liquid parameters define the thermodynamics and kinetics of the fermentation, all goals of syngas fermentation cannot be achieved in a single CSTR stage. The laboratory CSTR fermenter is essential in defining the parameters of successful syngas fermentation, but efficient and economical commercial syngas fermentation for biofuel production can be realized in carefully-designed packed column fermenters that provide multistage gas contact during fermentation. Rich syngas contact with high liquid volume at the column bottom will promote reduction of acid to alcohol; partially converted syngas will promote culture growth with low inhibition in the middle; and high mass transfer could convert residual $\mathrm{CO}$ and $\mathrm{H}_{2}$ before the spent gas exits the column at the top. These characteristics ensure product specificity, productivity and efficient energy conservation, which are all essential to process economy.

\section{Potential Products}

Growth of acetogens in syngas fermentation using a mineral-defined medium shows production of complex cell components from single carbon substrates, $\mathrm{CO}$ and $\mathrm{CO}_{2}$, with energy derived from $\mathrm{CO}$ and $\mathrm{H}_{2}$ [30]. This implies a reversal of glycolytic pathways to form pyruvate and then sugars that compose the membranes from the syngas components. Energy from ATP and reduced electron carriers sufficient to supply fermentation reactions that branch from the glycolytic pathway to form amino acids, nucleic acids and lipids is available in syngas fermentation through the chemiosmotic mechanisms that drive the membrane-bound ATPase and electron transfers. The accumulation of butyric acid, hexanoic acid, butanol and hexanol has been demonstrated for C. carboxidivorans [30], and a broad range of potential products awaits techniques developed to enhance accumulation.

Ethanol and acetic acid are products derived directly from acetyl-CoA without the expense of ATP. Ethanol that can be recovered by distillation is the most prominent product. Acetic acid requires more elaborate recovery, such as extraction, but is a high volume chemical and potentially could be produced by oxidation of ethanol. Ethylene, globally one of the highest selling chemicals, could be formed by dehydration of ethanol [104].

An additional ATP is expended by the cells to condense two acetyl-CoA to butyryl-CoA, which is converted to butyric acid and then to butanol in steps similar to ethanol production. Butanol is sought as a "drop-in" biofuel for use in existing petroleum infrastructure, as a solvent and as precursor for subsequent synthesis. Propionic acid, propanol, hexanoic acid, hexanol, acetone, isobutanol, butanediol, amino and fatty acids are other potential products proposed from syngas fermentation [34,35,105-107]. A biological water-gas shift is proposed to produce $\mathrm{H}_{2}$ [108], and syngas can be biologically converted to methane [109] so that syngas energy and subsequent products might be obtained from biological conversion of natural gas.

\section{Techno-Economic Analysis}

The annual ethanol production in the United States increased from 52 billion liters in 2010 to 59 billion liters in 2017 [110]. The global annual ethanol production increased from 50 billion liters 
in 2007 to 101 billion liters in 2016 [111]. These statistics show huge demand for ethanol worldwide. Ethanol produced globally is mostly made from grains and sugar cane. Corn ethanol and gasoline prices in the United States in April 2017 are about $\$ 0.43$ per liter and $\$ 0.44$ per liter, respectively [112]. Current corn ethanol prices are similar to prices reported in 1982 (Figure 5). However, current gasoline price is about $60 \%$ higher than in 1982. For lignocellulosic ethanol to compete in the fuel market, its selling price should be comparable to corn ethanol prices on an energy basis.

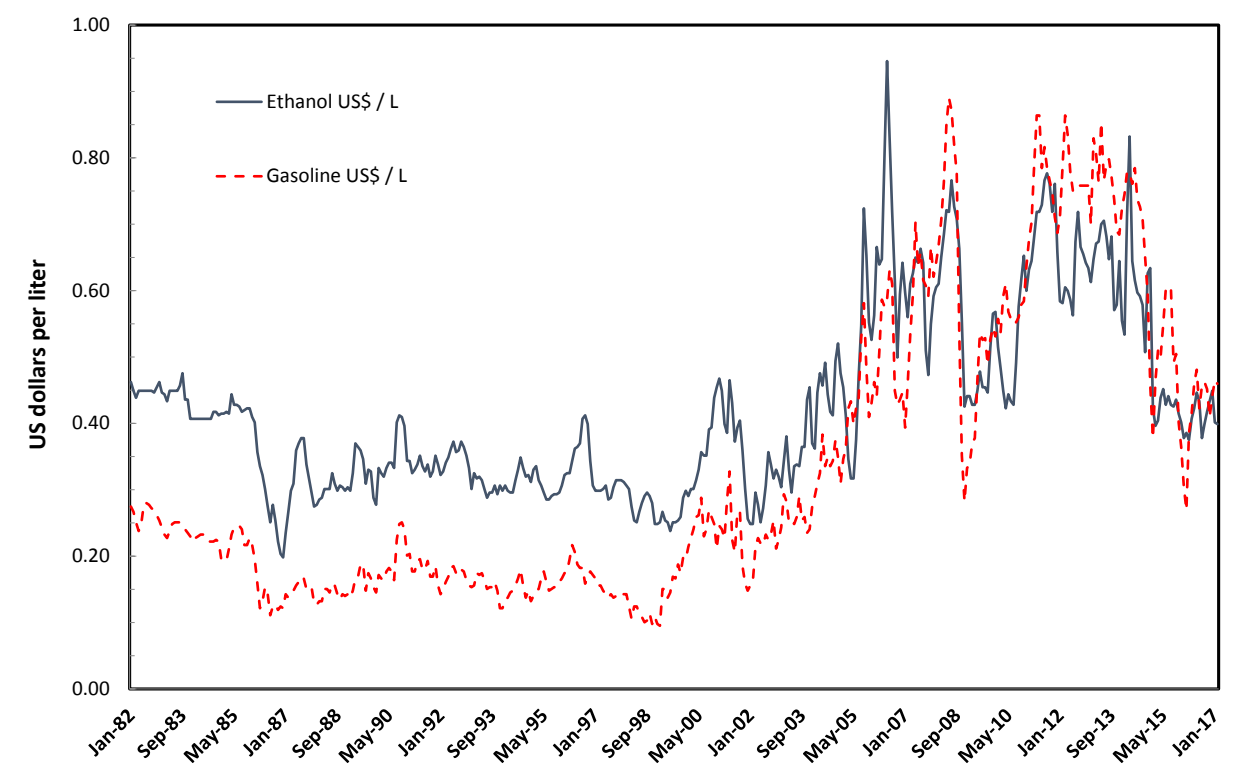

Figure 5. Historical prices of corn ethanol and gasoline in the United States [113].

Lignocellulosic biofuel producers experience delayed plans for commercialization due to difficulty in technology scale-up and securing financing with low petroleum and natural gas costs. Technological and economic challenges in commercialization of lignocellulosic biofuels must be solved to address increased world energy demand, concerns of climate change and to build a sustainable biofuel industry.

Techno-economic analysis (TEA) provides assessments of cost-competitiveness and market penetration potential of alternative biofuel production technologies to researchers, engineers, investors and policy makers [114]. TEA can also facilitate sensitivity analyses of key process parameters to improve feasibility and provide future directions for biofuels research. TEAs are typically based on process and plant design assumptions including experimentally-derived or assumed parameters to estimate process performance, biofuel cost and yield and capital and operating costs. The results obtained from TEA are strongly dependent on the models used and the assumptions made.

Several studies report TEA for the conversion of lignocellulosic biomass to ethanol using the enzymatic hydrolysis fermentation (EHF) process [115-118] and the gasification-mixed alcohol catalytic conversion (GMA) platform [5,119]. However, few studies were found on TEA for ethanol production through the hybrid gasification-syngas fermentation (GF) process [117,120]. TEAs of various thermochemical technologies for cellulosic biofuels have been recently reviewed [121].

Spath and Dayton [120] reported a minimum ethanol selling price (MESP) of $\$ 0.44 / \mathrm{L}$ for the GF process of 2206 metric tonnes per day (MTPD) with a feedstock cost of $\$ 38.70$ per metric tonnes (mT), as shown in Table 5. Piccolo and Bezzo [117] estimated that the cost of ethanol production via GF was about $30 \%$ higher than for EHF with an assumption of ethanol concentration in the fermentation beer three-fold higher in EHF. The higher ethanol cost using the GF process was due to additional cost for energy required in the distillation of beer containing $24 \mathrm{~g} / \mathrm{L}$ ethanol compared to $70 \mathrm{~g} / \mathrm{L}$ ethanol in EHF. The MESP for EHF was 5\% lower than for GF when ethanol concentration in the beer in the GF was assumed to be $50 \mathrm{~g} / \mathrm{L}$ due to higher ethanol yield with the EHF process [117]. However, MESP 
for EHF with ammonia fiber explosion pretreatment [122] was $4 \%$ higher than for GF with $50 \mathrm{~g} / \mathrm{L}$ ethanol [117]. For the GF process, the cost of biomass feedstock, ethanol concentration and ethanol yield were identified as the main contributors to the MESP.

Typically, total capital investment (TCI) of the GF process is higher than the EHF process due to the additional cost of the gasification system (Table 5). However, the GF process has the potential to achieve high ethanol yields ( $440 \mathrm{~L} / \mathrm{Mg}$ ) compared to $340 \mathrm{~L} / \mathrm{Mg}$ for the EHF process [123]. This is due to utilization of all components of the biomass, including lignin during gasification to produce syngas converted into ethanol. The type of gasifier used in thermochemical conversion technologies and pretreatment methods in the biochemical conversion platform greatly affect the production cost of biofuel $[118,122]$.

Table 5. Techno-economic analysis (TEA) of GF, GMA and EHF processes; all values in 2015 dollars.

\begin{tabular}{|c|c|c|c|c|c|c|}
\hline Process $^{a}$ & $\begin{array}{l}\text { Plant Size } \\
\text { (MTPD) }^{b}\end{array}$ & $\begin{array}{c}\text { Feedstock } \\
\text { Cost }(\$ / \mathrm{mT})\end{array}$ & $\begin{array}{c}\text { Ethanol Yield } \\
(\mathrm{L} / \mathrm{mT})\end{array}$ & $\begin{array}{l}\mathrm{TCI}^{\mathrm{c}} \\
\text { (M\$) }\end{array}$ & $\begin{array}{c}\text { MESP d } \\
(\$ / L)\end{array}$ & Reference \\
\hline \multirow[t]{3}{*}{ GF } & 2206 & 38.70 & 289 & $\mathrm{NR}^{\mathrm{e}}$ & 0.44 & [120] \\
\hline & 2030 & 80.13 & 204 & 575 & $1.32^{\mathrm{f}}$ & [117] \\
\hline & 2030 & 80.13 & 282 & NR & $1.07^{g}$ & \\
\hline \multirow[t]{2}{*}{ GMA } & 2140 & 88.74 & 236 & 578 & 0.86 & [5] \\
\hline & 2000 & 78.06 & 350 & 593 & 0.62 & [119] \\
\hline \multirow[t]{4}{*}{ EHF } & 2000 & 74.17 & 330 & 509 & 0.65 & [115] \\
\hline & 2030 & 80.13 & 310 & 301 & $1.01^{\mathrm{h}}$ & [117] \\
\hline & 2000 & 95.45 & 289 & 432 & $1.03^{i}$ & [122] \\
\hline & 2000 & 95.45 & 250 & 444 & $1.11^{\mathrm{j}}$ & \\
\hline
\end{tabular}

a GF: gasification-syngas fermentation; EHF: enzymatic hydrolysis fermentation; GMA: gasification-mixed alcohol catalytic conversion; ${ }^{\mathrm{b}}$ MTPD: metric tonnes per day; ${ }^{\mathrm{c}}$ TCI: total capital investment; ${ }^{\mathrm{d}}$ MESP: minimum ethanol selling price; ${ }^{\mathrm{e}} \mathrm{NR}$ : not reported; ${ }^{\mathrm{f}}$ ethanol concentration in the beer is $24 \mathrm{~g} / \mathrm{L}$; $\mathrm{g}$ ethanol concentration in the beer is $50 \mathrm{~g} / \mathrm{L} ;{ }^{\mathrm{h}}$ ethanol concentration in the beer is $70 \mathrm{~g} / \mathrm{L} ;^{\mathrm{i}}$ diluted acid pretreatment; ${ }^{\mathrm{j}}$ AFEX: ammonia fiber explosion.

Current TEA studies are based on technical data and assumptions for first generation biorefineries. Further technology advancements will provide stable, controlled and efficient biofuel conversion processes, which are expected to make future biorefineries feasible.

\section{Conclusions}

Thermochemical gasification of biomass and wastes combined with the simple robust conversion of $\mathrm{CO}$ and $\mathrm{H}_{2}$ by autotrophic acetogenic bacteria to various products provides a versatile and potentially economical process for the production of fuels and chemicals. Biomass and wastes are wide-spread feedstock resources that represent untapped economic opportunity and, often, environmental disposal problems. Production of fuels and chemicals from biomass will reduce economic reliance on fossil carbon and emission of greenhouse gases, approaching sustainable energy derived from solar input. The autotrophic bacteria that mediate syngas fermentation build the complex chemicals that comprise cell mass from the simple molecules $\mathrm{CO}, \mathrm{CO}_{2}$ and $\mathrm{H}_{2}$. This synthetic capability presents a staggering number of potential products from the enzyme platform of the native organisms. A more rigorous analysis of syngas mass transfer within an improved concept of the fermentation mechanisms allows the determination of thermodynamic and kinetic parameters inside the bacterial cells. These parameters can be incorporated in a mathematical model to advance process design and control for commercial use of syngas fermentation. The review of techno-economic analysis of gasification-syngas fermentation showed a competitive advantage of the hybrid gasification-syngas fermentation technology to make biofuels compared to gasification-mixed alcohol catalytic conversion and enzymatic hydrolysis fermentation processes. Further advancements in fundamental and applied research areas are essential to make biological gas conversion processes feasible for the production of new products in support of the chemical, petrochemical, agricultural, environmental and pharmaceutical industries. 
Acknowledgments: This research was supported by the Sun Grant Program-South Center No. DOTS59-07-G-00053, USDA-NIFA Project No. OKL03005 and the Oklahoma Agricultural Experiment Station.

Author Contributions: John R. Phillips, Raymond L. Huhnke and Hasan K. Atiyeh performed the analysis of the literature and wrote the paper.

Conflicts of Interest: The authors declare no conflict of interest.

\section{References}

1. Wilkins, M.R.; Atiyeh, H.K. Microbial production of ethanol from carbon monoxide. Curr. Opin. Biotechnol. 2011, 22, 326-330. [CrossRef] [PubMed]

2. Drake, H.L.; Gossner, A.S.; Daniel, S.L. Old acetogens, new light. Ann. N. Y. Acad. Sci. 2008, 1125, 100-128. [CrossRef] [PubMed]

3. Ramió-Pujol, S.; Ganigué, R.; Bañeras, L.; Colprim, J. How can alcohol production be improved in carboxydotrophic clostridia? Process Biochem. 2015, 50, 1047-1055. [CrossRef]

4. Singla, A.; Verma, D.; Lal, B.; Sarma, P.M. Enrichment and optimization of anaerobic bacterial mixed culture for conversion of syngas to ethanol. Bioresour. Technol. 2014, 172, 41-49. [CrossRef] [PubMed]

5. Valle, C.R.; Perales, A.L.V.; Vidal-Barrero, F.; Gomez-Barea, A. Techno-economic assessment of biomass-to-ethanol by indirect fluidized bed gasification: Impact of reforming technologies and comparison with entrained flow gasification. Appl. Energy 2013, 109, 254-266. [CrossRef]

6. Griffin, D.W.; Schultz, M.A. Fuel and chemical products from biomass syngas: A comparison of gas fermentation to thermochemical conversion routes. Environ. Progress Sustain. Energy 2012, 219-224. [CrossRef]

7. Energy Information Administration (EIA). Annual Energy Outlook; Department of Energy: Washington, DC, USA, 2012.

8. Energy Information Administration (EIA). International Energy Outlook; Department of Energy: Washington, DC, USA, 2013.

9. Balan, V.; Chiaramonti, D.; Kumar, S. Review of US and EU initiatives toward development, demonstration, and commercialization of lignocellulosic biofuels. Biofuels Bioprod. Biorefin. 2013, 7, 732-759. [CrossRef]

10. Energy Information Administration (EIA). Biofuels Issues and Trends; Department of Energy: Washington, DC, USA, 2012.

11. Liew, F.M.; Köpke, M.; Simpson, S.D. Gas fermentation for commercial biofuels production. In Liquid, Gaseous and Solid Biofuels_Conversion Techniques; Fang, Z., Ed.; InTech: Rijeka, Croatia, 2013; pp. 125-173.

12. Energy Information Administration (EIA). Annual Energy Outlook (US) with Projections to 2040; Department of Energy: Washington, DC, USA, 2015.

13. Perlack, R.D.; Stokes, B.J. U.S. Billion-Ton Update: Biomass Supply for a Bioenergy and Bioproducts Industry; Department of Energy: Washington, DC, USA, 2011.

14. Environmental Protection Agency. Municipal Solid Waste Generation, Recycling, and Disposal in the United States: Facts and Figures for 2012; Environmental Protection Agency: Washington, DC, USA, 2012.

15. Atsonios, K.; Christodoulou, C.; Koytsoumpa, E.I.; Panopoulos, K.D.; Kakaras, E. Plant design aspects of catalytic biosyngas conversion to higher alcohols. Biomass Bioenergy 2013, 53, 54-64. [CrossRef]

16. Ahmed, A.; Cateni, B.G.; Huhnke, R.L.; Lewis, R.S. Effects of biomass-generated producer gas constituents on cell growth, product distribution and hydrogenase activity of Clostridium carboxidivorans P7(T). Biomass Bioenergy 2006, 30, 665-672. [CrossRef]

17. Xu, D.; Tree, D.R.; Lewis, R.S. The effects of syngas impurities on syngas fermentation to liquid fuels. Biomass Bioenergy 2011, 35, 2690-2696. [CrossRef]

18. Woolcock, P.J.; Brown, R.C. A review of cleaning technologies for biomass-derived syngas. Biomass Bioenergy 2013, 52, 54-84. [CrossRef]

19. Ferry, J.G.; House, C.H. The stepwise evolution of early life driven by energy conservation. Mol. Biol. Evol. 2006, 23, 1286-1292. [CrossRef] [PubMed]

20. Fischer, F.; Lieske, R.; Winzer, K. Biological gas reactions II concerning the formation of acetic acid in the biological conversion of carbon oxide and carbonic acid with hydrogen to methane. Biochem. Z. 1932, 245, 2-12. 
21. Wieringa, K.T. Over het verwijnenvan waterstofen koolzuur onder anaerobe voorwaarden. Antonie Leeuwenhoek 1936, 3, 263-273. [CrossRef]

22. Collins, M.D.; Lawson, P.A.; Willems, A.; Cordoba, J.J.; Fernandezgarayzabal, J.; Garcia, P.; Cai, J.; Hippe, H.; Farrow, J.A.E. Thephylogeny of the genus Clostridium-Proposal of five new genera and eleven new species combinations. Int. J. Syst. Bacteriol. 1994, 44, 812-826. [CrossRef] [PubMed]

23. Fontaine, F.E. A new type of glucose fermentation by Clostridium thermoaceticum n. sp. J. Bacteriol. 1942, 43, 700-715.

24. Ragsdale, S.W. Enzymology of the Wood-Ljungdahl pathway of acetogenesis. Ann. N. Y. Acad. Sci. 2008, 1125, 129-136. [CrossRef] [PubMed]

25. Barik, S.; Prieto, S.; Harrison, S.B.; Clausen, E.C.; Gaddy, J.L. Biological Production of Alcohols from Coal through Indirect Liquefaction. Appl. Biochem. Biotechnol. 1988, 18, 363-378. [CrossRef]

26. Tanner, R.S.; Miller, L.M.; Yang, D. Clostridium ljungdahlii sp. nov., an Acetogenic Species in Clostridial rRNA Homology Group I. Int. J. Syste. Bacteriol. 1993, 43, 232-236. [CrossRef] [PubMed]

27. Worden, R.M.; Grethlein, A.J.; Jain, M.K.; Datta, R. Production of butanol and ethanol from synthesis gas via fermentation. Fuel 1991, 70, 615-619. [CrossRef]

28. Abrini, J.; Naveau, H.; Nyns, E.-J. Clostridium autoethanogenum, sp. nov., an anaerobic bacterium that produces ethanol from carbon monoxide. Arch. Microbiol. 1994, 161, 345-351. [CrossRef]

29. Liou, J.S.-C.; Balkwill, D.L.; Drake, G.R.; Tanner, R.S. Clostridium carboxidivorans sp. nov., a solvent-producing clostridium isolated from an agricultural settling lagoon, and reclassification of the acetogen Clostridium scatologenes strain SL1 as Clostridium drakei sp. nov. Int. J. Syst. Evol. Microbiol. 2005, 55, 2085-2091. [CrossRef] [PubMed]

30. Phillips, J.R.; Atiyeh, H.K.; Tanner, R.S.; Torres, J.R.; Saxena, J.; Wilkins, M.R.; Huhnke, R.L. Butanol and hexanol production in Clostridium carboxidivorans syngas fermentation: Medium development and culture techniques. Bioresour. Technol. 2015, 190, 114-121. [CrossRef] [PubMed]

31. Saxena, J. Development of an optimized and cost-effective medium for ethanol production by Clostridium strain P11. In Botany and Microbiology; University of Oklahoma: Norman, OK, USA, 2008; p. 131.

32. Allen, T.D.; Caldwell, M.E.; Lawson, P.A.; Huhnke, R.L.; Tanner, R.S. Alkalibaculum bacchi gen. nov., sp. nov., a CO-oxidizing, ethanol-producing acetogen isolated from livestock-impacted soil. Int. J. Syst. Evol. Microbiol. 2010, 60, 2483-2489. [CrossRef] [PubMed]

33. Liu, K.; Atiyeh, H.K.; Tanner, R.S.; Wilkins, M.R.; Huhnke, R.L. Fermentative production of ethanol from syngas using novel moderately alkaliphilic strains of Alkalibaculum bacchi. Bioresour. Technol. 2012, 104, 336-341. [CrossRef] [PubMed]

34. Liu, K.; Atiyeh, H.K.; Stevenson, B.S.; Tanner, R.S.; Wilkins, M.R.; Huhnke, R.L. Continuous syngas fermentation for the production of ethanol, n-propanol and n-butanol. Bioresour. Technol. 2014, 151, 69-77. [CrossRef] [PubMed]

35. Liu, K.; Atiyeh, H.K.; Stevenson, B.S.; Tanner, R.S.; Wilkins, M.R.; Huhnke, R.L. Mixed culture syngas fermentation and conversion of carboxylic acids into alcohols. Bioresour. Technol. 2014, 152, 337-346. [CrossRef] [PubMed]

36. Xu, S.; Fu, B.; Zhang, L.; Liu, H. Bioconversion of $\mathrm{H}_{2} / \mathrm{CO}_{2}$ by acetogen enriched cultures for acetate and ethanol production: The impact of pH. World J. Microbiol. Biotechnol. 2015, 31, 941-950. [CrossRef] [PubMed]

37. Tanner, R.S. Cultivation of Bacteria and Fungi. In Manual of Environmental Microbiology, 3rd ed.; ASM Press: Washington, DC, USA, 2007; pp. 69-78.

38. Maddipati, P.; Atiyeh, H.K.; Bellmer, D.D.; Huhnke, R.L. Ethanol production from syngas by Clostridium strain P11 using corn steep liquor as a nutrient replacement to yeast extract. Bioresour. Technol. 2011, 102, 6494-6501. [CrossRef] [PubMed]

39. Saxena, J.; Tanner, R.S. Optimization of a corn steep medium for production of ethanol from synthesis gas fermentation by Clostridium ragsdalei. World J. Microbiol. Biotechnol. 2012, 28, 1553-1561. [CrossRef] [PubMed]

40. Kundiyana, D.K.; Huhnke, R.L.; Maddipati, P.; Atiyeh, H.K.; Wilkins, M.R. Feasibility of incorporating cotton seed extract in Clostridium strain P11 fermentation medium during synthesis gas fermentation. Bioresour. Technol. 2010, 101, 9673-9680. [CrossRef] [PubMed]

41. Phillips, J.R.; Klasson, K.T.; Clausen, E.C.; Gaddy, J.L. Biological production of ethanol from coal synthesis gas - Medium development studies. Appl. Biochem. Biotechnol. 1993, 39, 559-571. [CrossRef] 
42. Cramer, W.A.; Knaff, D.B. Energy transduction in biological membranes: A textbook of bioenergetics. In Springer Advanced Texts in Chemistry; edn Springer Study; Springer-Verlag: New York, NY, USA, 1991.

43. Roberts, J.R.; Lu, W.P.; Ragsdale, S.W. Acetyl-coenzyme A synthesis from methyltetrahydrofolate, CO, and coenzyme A by enzymes purified from Clostridium thermoaceticum: Attainment of in vivo rates and identification of rate-limiting steps. J. Bacteriol. 1992, 174, 4667-4676. [CrossRef] [PubMed]

44. Ljungdahl, L.G. The Autotrophic Pathway of Acetate Synthesis in Acetogenic Bacteria. Annu. Rev. Microbiol. 1986, 40, 415-450. [CrossRef] [PubMed]

45. Ragsdale, S.W.; Lindahl, P.A.; Münck, E. Mössbauer, EPR, and optical studies of the corrinoid/iron-sulfur protein involved in the synthesis of acetyl coenzyme A by Clostridium thermoaceticum. J. Biol. Chem. 1987, 262, 14289-14297. [PubMed]

46. Yamamoto, I.; Saiki, T.; Liu, S.M.; Ljungdahl, L.G. Purification and properties of NADP-dependent formate dehydrogenase from Clostridium thermoaceticum, a tungsten-selenium-iron protein. J. Biol. Chem. 1983, 258, 1826-1832. [PubMed]

47. Mejillano, M.R.; Jahansouz, H.; Matsunaga, T.O.; Kenyon, G.L.; Himes, R.H. Formation and utilization of formyl phosphate by N10-formyltetrahydrofolate synthetase: Evidence for formyl phosphate as an intermediate in the reaction. Biochemistry 1989, 28, 5136-5145. [CrossRef] [PubMed]

48. Sun, A.Y.; Ljungdahl, L.; Wood, H.G. Total synthesis of acetate from $\mathrm{CO}_{2}$ II. Purification and properties of formyltetrahydrofolate synthetase from Clostridium thermoaceticum. J. Bacteriol. 1969, 98, 842-844. [PubMed]

49. Ljungdahl, L.G.; O’Brien, W.E.; Moore, M.R.; Liu, M.-T. Methylenetetrahydrofolate dehydrogenase from Clostridium formicoaceticum and methylenetetrahydrofolate dehydrogenase, methenyltetrahydrofolate cyclohydrolase (combined) from Clostridium thermoaceticum. In Methods in Enzymology; Donald, B., McCormick, L.D.W., Eds.; Academic Press: Olrando, FL, USA, 1980; pp. 599-609.

50. Park, E.Y.; Clark, J.E.; de Vartanian, D.V.; Ljungdahl, L.G. 5,10-methylenetetrahydrofolate Reductases: Iron-sulfur-zinc flavoproteins. In Chemistry and Biochemistry of flavoenzymes; Müller, F., Ed.; CRC Press: Boca Raton, FL, USA, 1991; pp. 389-400.

51. Lu, W.P.; Harder, S.R.; Ragsdale, S.W. Controlled potential enzymology of methyl transfer reactions involved in acetyl-CoA synthesis by $\mathrm{CO}$ dehydrogenase and the corrinoid/iron-sulfur protein from Clostridium thermoaceticum. J. Biol. Chem. 1990, 265, 3124-3133. [PubMed]

52. Drake, H.L.; Hu, S.I.; Wood, H.G. Purification of five components from Clostridium thermoaceticum which catalyze synthesis of acetate from pyruvate and methyltetrahydrofolate. Properties of phosphotransacetylase. J. Biol. Chem. 1981, 256, 11137-11144. [PubMed]

53. White, H.; Strobl, G.; Feicht, R.; Simon, H. Carboxylic acid reductase: A new tungsten enzyme catalyses the reduction of non-activated carboxylic acids to aldehydes. Eur. J. Biochem. 1989, 184, 89-96. [CrossRef] [PubMed]

54. Fraisse, L.; Simon, H. Observations on the reduction of non-activated carboxylates by Clostridium formicoaceticum with carbon monoxide or formate and the Influence of various viologens. Arch. Microbiol. 1988, 150, 381-386. [CrossRef]

55. Phillips, J.R.; Clausen, E.C.; Gaddy, J.L. Synthesis gas as substrate for the biological production of fuels and chemicals. Appl. Biochem. Biotechnol. 1994, 45, 145-157. [CrossRef]

56. Latif, H.; Zeidan, A.A.; Nielsen, A.T.; Zengler, K. Trash to treasure: Production of biofuels and commodity chemicals via syngas fermenting microorganisms. Curr. Opin. Biotechnol. 2014, 27, 79-87. [CrossRef] [PubMed]

57. Liew, F.; Martin, M.E.; Tappel, R.C.; Heijstra, B.D.; Mihalcea, C.; Köpke, M. Gas fermentation-A flexible platform for commercial scale production of low-carbon-fuels and chemicals from waste and renewable feedstocks. Front. Microbiol. 2016, 7, 1-28. [CrossRef] [PubMed]

58. Hurst, K.M.; Lewis, R.S. Carbon monoxide partial pressure effects on the metabolic process of syngas fermentation. Biochem. Eng. J. 2010, 48, 159-165. [CrossRef]

59. Vega, J.L.; Prieto, S.; Elmore, B.B.; Clausen, E.C.; Gaddy, J.L. The Biological Production of Ethanol from Synthesis Gas. Appl. Biochem. Biotechnol. 1989, 20, 781-797. [CrossRef]

60. Ukpong, M.N.; Atiyeh, H.K.; de Lorme, M.J.M.; Liu, K.; Zhu, X.; Tanner, R.S.; Wilkins, M.R.; Stevenson, B.S. Physiological response of Clostridium carboxidivorans during conversion of synthesis gas to solvents in a gas-fed bioreactor. Biotechnol. Bioeng. 2012, 109, 2720-2728. [CrossRef] [PubMed] 
61. Ezeji, T.; Milne, C.; Price, N.D.; Blaschek, H.P. Achievements and perspectives to overcome the poor solvent resistance in acetone and butanol-producing microorganisms. Appl. Microbiol. Biotechnol. 2010, 85, 1697-1712. [CrossRef] [PubMed]

62. Köpke, M.; Mihalcea, C.; Bromley, J.C.; Simpson, S.D. Fermentative production of ethanol from carbon monoxide. Curr. Opin. Biotechnol. 2011, 22, 320-325. [CrossRef] [PubMed]

63. Seravalli, J.; Ragsdale, S.W. Channeling of carbon monoxide during anaerobic carbon dioxide fixation. Biochemistry 2000, 39, 1274-1277. [CrossRef] [PubMed]

64. Isom, C.E.; Nanny, M.A.; Tanner, R.S. Improved conversion efficiencies for $\mathrm{n}$-fatty acid reduction to primary alcohols by the solventogenic acetogen "Clostridium ragsdalei". J. Ind. Microbiol. Biotechnol. 2015, 42, $29-38$. [CrossRef] [PubMed]

65. Shanmugasundaram, T.; Wood, H.G. Interaction of ferredoxin with carbon monoxide dehydrogenase from Clostridium thermoaceticum. J. Biol. Chem. 1992, 267, 897-900. [PubMed]

66. Buckel, W.; Thauer, R.K. Energy conservation via electron bifurcating ferredoxin reduction and proton/Na+ translocating ferredoxin oxidation. Biochim. Biophys. Acta-Bioenerg. 2013, 1827, 94-113. [CrossRef] [PubMed]

67. Poehlein, A.; Schmidt, S.; Kaster, A.K.; Goenrich, M.; Vollmers, J.; Thurmer, A.; Bertsch, J.; Schuchmann, K.; Voigt, B.; Hecker, M.; et al. An ancient pathway combining carbon dioxide fixation with the generation and utilization of a sodium ion gradient for ATP synthesis. PLoS ONE 2012, 7, e33439. [CrossRef] [PubMed]

68. Tremblay, P.L.; Zhang, T.; Dar, S.A.; Leang, C.; Lovley, D.R. The Rnf complex of Clostridium ljungdahlii is a proton-translocating ferredoxin:NAD ${ }^{+}$oxidoreductase essential for autotrophic growth. mBio 2013, 4, 1-12. [CrossRef] [PubMed]

69. Schuchmann, K.; Muller, V. Autotrophy at the thermodynamic limit of life: A model for energy conservation in acetogenic bacteria. Nat. Rev. Microbiol. 2014, 12, 809-821. [CrossRef] [PubMed]

70. Hugenholtz, J.; Ivey, D.M.; Ljungdahl, L.G. Carbon monoxide-driven electron transport in Clostridium thermoautotrophicum membranes. J. Bacteriol. 1987, 169, 5845-5847. [CrossRef] [PubMed]

71. Thauer, R.K.; Jungermann, K.; Decker, K. Energy conservation in chemotrophic anaerobic bacteria. Microbiol. Mol. Biol. Rev. 1977, 41, 100-180.

72. Das, A.; Ljungdahl, L.G. Composition and primary structure of the F1F0 ATP synthase from the obligately anaerobic bacterium Clostridium thermoaceticum. J. Bacteriol. 1997, 179, 3746-3755. [CrossRef] [PubMed]

73. Ivey, D.M.; Ljungdahl, L.G. Purification and characterization of the F1-ATPase from Clostridium thermoaceticum. J. Bacteriol. 1986, 165, 252-257. [CrossRef] [PubMed]

74. Nakamoto, R.K.; Scanlon, J.A.B.; Al-Shawi, M.K. The rotary mechanism of the ATP synthase. Arch. Biochem. Biophys. 2008, 476, 43-50. [CrossRef] [PubMed]

75. Von Ballmoos, C.; Cook, G.M.; Dimroth, P. Unique rotary ATP synthase and its biological diversity. Annu. Rev. Biophys. 2008, 37, 43-64. [CrossRef] [PubMed]

76. Ragsdale, S.W. Enzymology of the acetyl-CoA pathway of $\mathrm{CO}_{2}$ fixation. Critical Rev. Biochem. Mol. Biol. 1991, 26, 261-300. [CrossRef] [PubMed]

77. Hougen, O.A.; Watson, K.M.; Ragatz, R.A. Chemical Process Principles; Wiley: New York, NY, USA, 1954.

78. Bird, R.B.; Stewart, W.E.; Lightfoot, E.N. Transport Phenomena, 2nd ed.; Wiley: New York, NY, USA, 2002.

79. Charpentier, J.-C. Mass-transfer rates in gas-liquid absorbers and reactors. In Advances in Chemical Engineering; Drew, T.B., Cokelet, G.R., Hooper, J.W., Vermeulen, T, Eds.; Academic Press: Olrando, FL, USA, 1981; pp. 1-133.

80. Bailey, J.E.; Ollis, D.F. Biochemical Engineering Fundamentals; McGraw-Hill: New York, NY, USA, 1986.

81. McCabe, W.L.; Smith, J.C. Unit Operations of Chemical Engineering; McGraw-Hill: New York, NY, USA, 1976.

82. Munasinghe, P.C.; Khanal, S.K. Syngas fermentation to biofuel: Evaluation of carbon monoxide mass transfer coefficient $\left(\mathrm{k}_{\mathrm{L}} \mathrm{a}\right)$ in different reactor configurations. Biotechnol. Prog. 2010, 26, 1616-1621. [CrossRef] [PubMed]

83. Klasson, K.T.; Ackerson, M.D.; Clausen, E.C.; Gaddy, J.L. Mass transport in bioreactors for coal synthesis gas fermentation. Abstr. Pap. Am. Chem. Soc. 1992, 1924-1930.

84. Shen, Y.W.; Brown, R.; Wen, Z.Y. Enhancing mass transfer and ethanol production in syngas fermentation of Clostridium carboxidivorans P7 through a monolithic biofilm reactor. Appl. Energy 2014, 136, 68-76. [CrossRef]

85. Vega, J.L.; Antorrena, G.M.; Clausen, E.C.; Gaddy, J.L. Study of gaseous substrate fermentations: Carbon monoxide conversion to acetate. 2. continuous culture. Biotechnol. Bioeng. 1989, 34, 785-793. [CrossRef] [PubMed] 
86. Shen, Y.; Brown, R.; Wen, Z. Syngas fermentation of Clostridium carboxidivoran P7 in a hollow fiber membrane biofilm reactor: evaluating the mass transfer coefficient and ethanol production performance. Biochem. Eng. J. 2014, 85, 21-29. [CrossRef]

87. Orgill, J.J.; Atiyeh, H.K.; Devarapalli, M.; Phillips, J.R.; Lewis, R.S.; Hunke, R.L. A comparison of mass transfer coefficients between trickle bed, hollow fiber membrane and stirred tank reactors. Bioresour. Technol. 2013, 133, 340-346. [CrossRef] [PubMed]

88. Nicholls, D.G.; Ferguson, S.J. Bioenergetics; Academic Press: Olrando, FL, USA, 2002.

89. Hu, P.; Bowen, S.H.; Lewis, R.S. A thermodynamic analysis of electron production during syngas fermentation. Bioresour. Technol. 2011, 102, 8071-8076. [CrossRef] [PubMed]

90. Lehninger, A.L. Principles of Biochemistry; Worth Publishers: New York, NY, USA, 1982.

91. Bar-Even, A. Does acetogenesis really require especially low reduction potential? Biochim. Biophys. Acta 2013, 1827, 395-400. [CrossRef] [PubMed]

92. Shuler, M.L.; Kargi, F. Bioprocess Engineering Basic Concepts; Prentice Hall PTR: Upper Saddle River, NJ, USA, 2002.

93. Chen, J.; Gomez, J.A.; Hoffner, K.; Barton, P.I.; Henson, M.A. Metabolic modeling of synthesis gas fermentation in bubble column reactors. Biotechnol. Biofuels 2015, 8, 1-12. [CrossRef]

94. Krivoruchko, A.; Zhang, Y.; Siewers, V.; Chen, Y.; Nielsen, J. Microbial acetyl-CoA metabolism and metabolic engineering. Metab. Eng. 2015, 28, 28-42. [CrossRef] [PubMed]

95. Bredwell, M.D.; Srivastava, P.; Worden, R.M. Reactor design issues for synthesis-gas fermentations. Biotechnol. Prog. 1999, 15, 834-844. [CrossRef] [PubMed]

96. Rogers, P.; Chen, J.-S.; Zidwick, M.J. Organic acid and solvent production. In The Prokaryotes; Dworkin, M., Falkow, S., Rosenberg, E., Schleifer, K.-H., Stackebrandt, E., Eds.; Springer: New York, NY, USA, 2006; pp. 511-755.

97. Straub, M.; Demler, M.; Weuster-Botz, D.; Durre, P. Selective enhancement of autotrophic acetate production with genetically modified Acetobacterium woodii. J. Biotechnol. 2014, 178, 67-72. [CrossRef] [PubMed]

98. Klasson, K.T.; Ackerson, C.M.D.; Clausen, E.C.; Gaddy, J.L. Biological conversion of synthesis gas into fuels. Int. J. Hydrogen Energy 1992, 17, 281-288. [CrossRef]

99. Atiyeh, H.K.; Phillips, J.R.; Huhnke, R.L. Fermentation Control for Optimization of Syngas Utilization. World Intellectual Property Organization: Geneva, Switzerland; WO2016077778 A1, 2016.

100. Kundiyana, D.K.; Huhnke, R.L.; Wilkins, M.R. Effect of nutrient limitation and two-stage continuous fermentor design on productivities during "Clostridium ragsdalei" syngas fermentation. Bioresour. Technol. 2011, 102, 6058-6064. [CrossRef] [PubMed]

101. Devarapalli, M.; Atiyeh, H.K.; Phillips, J.R.; Lewis, R.S.; Huhnke, R.L. Ethanol production during semi-continuous syngas fermentation in a trickle bed reactor using Clostridium ragsdalei. Bioresour. Technol. 2016, 209, 56-65. [CrossRef] [PubMed]

102. Devarapalli, M.; Lewis, R.S.; Atiyeh, H.K. Continuous ethanol production from synthesis gas by Clostridium ragsdalei in a trickle-bed reactor. Fermentation 2017, 3, 1-13. [CrossRef]

103. Richter, H.; Martin, M.E.; Angenent, L.T. A two-stage continuous fermentation system for conversion of syngas into ethanol. Energies 2013, 6, 3987-4000. [CrossRef]

104. Nguyen, T.T.N.; Belliere-Baca, V.; Rey, P.; Millet, J.M.M. Efficient catalysts for simultaneous dehydration of light alcohols in gas phase. Catal. Sci. Technol. 2015, 5, 3576-3584. [CrossRef]

105. Kopke, M.; Mihalcea, C.; Liew, F.M.; Tizard, J.H.; Ali, M.S.; Conolly, J.J.; Al-Sinawi, B.; Simpson, S.D. 2,3-Butanediol production by acetogenic bacteria, an alternative route to chemical synthesis, using industrial waste gas. Appl. Environ. Microbiol. 2011, 77, 5467-5475. [CrossRef] [PubMed]

106. Dürre, P. Butanol formation from gaseous substrates. FEMS Microbiol. Lett. 2016, 363, 1-7. [CrossRef] [PubMed]

107. Hu, P.; Chakraborty, S.; Kumar, A.; Woolston, B.; Liu, H.; Emerson, D.; Stephanopoulos, G. Integrated bioprocess for conversion of gaseous substrates to liquids. Proc. Natl. Acad. Sci. USA 2016, 113, 3773-3778. [CrossRef] [PubMed]

108. Pakpour, F.; Najafpour, G.; Tabatabaei, M.; Tohidfar, M.; Younesi, H. Biohydrogen production from CO-rich syngas via a locally isolated Rhodopseudomonas palustris PT. Bioprocess Biosyst. Eng. 2014, 37, 923-930. [CrossRef] [PubMed] 
109. Youngsukkasem, S.; Chandolias, K.; Taherzadeh, M.J. Rapid bio-methanation of syngas in a reverse membrane bioreactor: Membrane encased microorganisms. Bioresour. Technol. 2015, 178, 334-340. [CrossRef] [PubMed]

110. EIA: 4-Week average U.S. Oxygenate Plant Production of Fuel Tthanol (Thousand Barrels Per Day); Energy Department of Energy Information Administration: Washington, DC, USA, 2017.

111. Renewable Fuels Association (RFA). World Fuel Ethanol Production; Renewable Fuels Association: Washington, DC, USA, 2016.

112. Nasdaq. Ethanol Futures. 2017. Available online: http://www.nasdaq.com/markets/ethanol.aspx (accessed on 27 April 2017).

113. USDA NASS, Quick Stats Database. USDA ERS-U.S. Bioenergy Statistics: Fuel Ethanol, Corn and Gasoline Prices; Service UER. USDA Economic Research Service: Washington, DC, USA, 2017.

114. Klein-Marcuschamer, D.; Oleskowicz-Popiel, P.; Simmons, B.A.; Blanch, H.W. Technoeconomic analysis of biofuels: A wiki-based platform for lignocellulosic biorefineries. Biomass Bioenergy 2010, 34, 1914-1921. [CrossRef]

115. Humbird, D.; Davis, R.; Tao, L.; Kinchin, C.; Hsu, D.; Aden, A.; Schoen, P.; Lukas, J.; Olthof, B.; Worley, M. Process Design and Economics for Biochemical Conversion of Lignocellulosic Biomass to Ethanol: Dilute-Acid Pretreatment and Enzymatic Hydrolysis of Corn Stover; National Renewable Energy Laboratory (NREL): Golden, CO, USA, 2011.

116. Dwivedi, P.; Alavalapati, J.R.; Lal, P. Cellulosic ethanol production in the United States: Conversion technologies, current production status, economics, and emerging developments. Energy Sustain. Dev. 2009, 13, 174-182. [CrossRef]

117. Piccolo, C.; Bezzo, F. A techno-economic comparison between two technologies for bioethanol production from lignocellulose. Biomass Bioenergy 2009, 33, 478-491. [CrossRef]

118. Anex, R.P.; Aden, A.; Kazi, F.K.; Fortman, J.; Swanson, R.M.; Wright, M.M.; Satrio, J.A.; Brown, R.C.; Daugaard, D.E.; Platon, A. Techno-economic comparison of biomass-to-transportation fuels via pyrolysis, gasification, and biochemical pathways. Fuel 2010, 89, S29-S35. [CrossRef]

119. Dutta, A.; Talmadge, M.; Hensley, J.; Worley, M.; Dudgeon, D.; Barton, D.; Groenendijk, P.; Ferrari, D.; Stears, B.; Searcy, E. Techno-economics for conversion of lignocellulosic biomass to ethanol by indirect gasification and mixed alcohol synthesis. Environ. Progress Sustain. Energy 2012, 31, 182-190. [CrossRef]

120. Spath, P.L.; Dayton, D.C. Preliminary Screening-Technical and Economic Assessment of Synthesis Gas to Fuels and Chemicals with Emphasis on the Potential for Biomass-Derived Syngas. 2003. Available online: http:/ / oai.dtic.mil/oai/oai?verb=getRecord\&metadataPrefix=html\&identifier=ADA436529 (accessed on 27 April 2017).

121. Brown, T.R. A techno-economic review of thermochemical cellulosic biofuel pathways. Bioresour. Technol. 2015, 178, 166-176. [CrossRef] [PubMed]

122. Kazi, F.K.; Fortman, J.A.; Anex, R.P.; Hsu, D.D.; Aden, A.; Dutta, A.; Kothandaraman, G. Techno-economic comparison of process technologies for biochemical ethanol production from corn stover. Fuel 2010, 89, S20-S28. [CrossRef]

123. Tanner, R.S. Production of ethanol from synthesis gas. In Bioenergy; Wall, J.D., Harwood, C.S., Demain, A.L., Eds.; American Society of Microbiology: Washington, DC, USA, 2008; pp. 147-151.

(C) 2017 by the authors. Licensee MDPI, Basel, Switzerland. This article is an open access article distributed under the terms and conditions of the Creative Commons Attribution (CC BY) license (http:/ / creativecommons.org/licenses/by/4.0/). 